\title{
A Case Study of Two Failures of a High Cut-slope in the Northeastern Area of Sichuan, China
}

\author{
Jianfeng Chen \\ Tongji University \\ Changcheng Du ( $\nabla$ duchangcheng@tongji.edu.cn ) \\ Tongji University https://orcid.org/0000-0002-6427-2510

\section{Zhang Qingzhao} \\ Tongji University

\section{Xiaopeng Guo} \\ China Geological Survey \\ Jianfeng Xue \\ University of New South Wales \\ Boan Jang \\ Kangwon National University
}

\section{Research Article}

Keywords: Cut-slope, Failure, Anchor cable grid beam, Rainfall, Finite element analysis, Factor of safety

Posted Date: February 10th, 2022

DOI: https://doi.org/10.21203/rs.3.rs-1148285/v1

License: (c) (i) This work is licensed under a Creative Commons Attribution 4.0 International License.

Read Full License 


\section{Abstract}

A high cut-slope in the northeast of Sichuan Province, China failed after excavation followed by rainfall. A second slope failure occurred under heavy rainfall a few days after being reinforced with anchor cables and grid beams. In this study, the detailed information and the failure history of the cut-slope were first presented. A series of numerical simulations were then conducted using finite element method (FEM) to analyze the slope stability and explore the failure mechanism. The numerical analyses found that the slope failures should not be simply attributed to rainfall. Other lessons have been learned from these two failures. They are: mis-characterization of the geological and hydraulic conditions of the site, poor understanding of the reaction of strongly weathered argillaceous shale materials with weak interlayers to water, and failing to implement proper drainage system in the slope after placing shotcrete on the slope surface. These resulted in the wrong measures to protect the cut-slope and the improper remediation works to stabilize the failed slope. The bond section of the anchor cable should be installed in the moderately weathered rock layer rather than strongly weathered layer with weak planes. The multiple failures of the slope warned all the parties that proper understanding of the geological and hydrological conditions of the site and the material properties is the starting point of any design and construction works.

\section{Introduction}

Landslides are common natural hazards in mountainous areas, especially during rainy seasons and earthquakes. Sichuan Province is located in southwest China, and numerous landslides occur each year. Landslides in this area are triggered by many influencing factors, including rainfall, earthquakes, and construction activities (Huang, 2009; Yin, 2011; Kazeev and Postoev, 2017; Wang et al., 2019; Zhang et al., 2021). With rapid urbanization and construction of infrastructures, some natural slopes need to be cut for roads or other facilities. However, due to the lack of attention to the unfavorable geological structures during the initial investigation, the slope after excavation is likely to fail (Huang et al. 2013; Sun et al. 2018; Xue et al., 2018; Ersöz et al., 2021).

To prevent the occurrence of slope instability after cutting, stabilizing measures are usually required. Among the various reinforcing measures, due to the unique advantages of high strength, simple construction, and economic benefits, anchor cables have been widely used for the slope stabilization, such as large-scale landslide remediation (Barla et al., 2013; Song and Cui, 2016), cut-slope reinforcement (Sun et al., 2010a; Li et al., 2014; Li et al., 2016), and high-steep rock slope stabilization (Chen et al., 2017; Ma et al., 2017; Chen et al., 2018). Currently, many scholars have investigated the reinforcing mechanism, and deformation and failure behaviors of the anchor cable by means of laboratory tests and/or numerical simulations (Ding et al., 2002; Cai and Ugai, 2003; Jiang et al., 2015; Lin et al., 2017; Li et al., 2019). In addition, the stability and performance of the slope reinforced with anchor cables were studied based on the field tests (Chen et al., 2018; Bi et al., 2019). Although the slopes have been stabilized, failure of the reinforced slopes would occur due to the failure of the anchor cables or external factors including inappropriate cutting, rainfall, earthquake and the lack of proper site investigation (Sun et al., 
2012; Zhang et al., 2012; Sun et al., 2013a; Jeng and Chen, 2013; Wang et al., 2013; Song and Cui, 2016; Chen et al., 2017). Most of previous studies reported the single failure analysis of the cut-slope through field investigation, experiments and/or numerical modeling. However, the studies concerning the multiple failures of the cut-slope, even after reinforcement, are still limited. Generally, the previous slope failure could trigger the subsequent failures, thus increasing the costs of remedial works. For example, a cutslope reported by Lee and Hencher (2009) failed six times even after several different remedial schemes. The repeated slope failures were attributed to insufficient geological and hydrogeological investigation, and inadequate interpretation of ground conditions prior to design, which caused that the height of this cut-slope had increased from $45 \mathrm{~m}$ to $155 \mathrm{~m}$ over a period of 7 years, and the cost had increased from 3.3 million to 26 million US dollars. The adequate understanding of the contributing factors and triggering mechanisms is vital to the slope stability and effectiveness of mitigation measures. The failure mechanism with respect to multiple slope failures needs to be further investigated and understood.

This paper reports two failures of a high cut-slope in Sichuan Province, Southwest China. The slope failed after excavation at the toe followed by rainfall. After failure, the slope was quickly reinforced with anchor cables and grid beams. Shortly after reinforcement, it failed again after heavy rainfall. The possible failure mechanisms and causes contributing to the slope failure were investigated using finite element method (FEM) in the two-dimensional finite-element program, PLAXIS, Version 8.2 (Brinkgreve et al., 2004). This research performed a comprehensive study to identify the possible causes of two slope failures based on the results of field investigation and numerical modeling. Some lessons learned from investigations on the slope failures were obtained. The analysis results of the case study can provide a significant reference for the design of similar projects to prevent slope failures.

\section{Regional Geology And Hydrogeology}

The study area is located in the northeast of Sichuan Province, China. It is composed of Quaternary artificial fill $\left(\mathrm{Q}_{4}{ }^{\mathrm{ml}}\right)$, Quaternary landslide deposit $\left(\mathrm{Q}_{4}{ }^{\mathrm{del}}\right)$, and Quaternary colluvium $\left(\mathrm{Q}_{4}{ }^{\mathrm{col}+\mathrm{dl}}\right)$, and Silurian Longmaxi Formation $\left(\mathrm{S}_{1} \mathrm{Im}^{4}\right)$. The Silurian Longmaxi Formation consists of strongly weathered argillaceous shale, moderately weathered argillaceous shale and moderately weathered silty shale. The moderately weathered argillaceous shale layer and moderately weathered silty shale layer dip towards the slope with a dip angle from $18^{\circ}$ to $45^{\circ}$, which is likely to cause the translational deep sliding in the rock layers.

As shown in Fig. 1, a normal fault (F1) with NWW-SEE strike runs through the east side of the cut-slope. The fault is a non-active fault, which has little effect on the stability of the slope. A syncline strikes southeast with the bearing of $120^{\circ}$. The dip directions and dip angles of the bedding planes of the syncline are $\left(50^{\circ}, 25^{\circ}\right)$ and $\left(175^{\circ}, 40^{\circ}\right)$, respectively. The ground water could accumulate at the core of the syncline (see Fig. 2a). As shown in Fig. 2b, at the toe of the slope, several small sinkholes were observed around the core of the syncline with the groundwater flowing out of the holes, which is unfavorable to the slope stability. Three well-developed gullies (R1, R2 and R3) flow into the two top corners of the excavated slope (see Fig. 3). These gullies are mostly recharged by the rainfall. The study area lies in the seismically 
active region of China and the basic earthquake intensity of this area is classified as degree VII. However, no destructive earthquake activities have been recorded and thus the earthquakes have very limited effect on the slope stability.

The study area features a subtropical monsoon climate, with the rainy season ranging from July to September. The precipitation in the rainy season accounts for more than $60 \%$ of the annual rainfall. The mean annual rainfall is $866.6 \mathrm{~mm}$ with the record highest daily precipitation of $96.1 \mathrm{~mm}$. In this area, groundwater is mainly recharged by the atmospheric precipitation, which is controlled by local topography and stratigraphy. The ground water is in the forms of loose-rocks pore water and bedrock fissure water (Fan et al., 2016). The former accumulates in the Quaternary soil layer and high-permeable colluvium in the upper part of the slope.

\section{Description Of The Project}

The original slope was excavated at an elevation ranging from $606 \mathrm{~m}$ at the toe to $696 \mathrm{~m}$ at the crest (see Fig. 4). The excavation was finished at the beginning of 2013. Berms with the width of $2.5 \mathrm{~m}$ to $3.0 \mathrm{~m}$ were constructed at the interval of $10 \mathrm{~m}$ in height along the slope. The cutting was constructed at $1.6 \mathrm{H}$ : $1 \mathrm{~V}$ (horizontal: vertical) in the soil layer and $1.25 \mathrm{H}: 1 \mathrm{~V}$ in the rock layer, with an overall slope angle of $35^{\circ}$. The cut-slope faced northwest with the bearing angle of $343^{\circ}$. The maximum height of the cut-slope was $100.5 \mathrm{~m}$. The soil profile of the slope was composed of pebbly silty clay (about $10 \mathrm{~m}$ thick), strongly weathered argillaceous shale (about $11 \mathrm{~m}$ thick) with fractures, joints and weak structural planes, moderately weathered argillaceous shale and moderately weathered silty shale from top to bottom, as shown in Fig. 4. The pebbly silty clay had the gravel content of $15-25 \%$ and the particle size of the gravels ranged from 2 to $20 \mathrm{~cm}$. The strongly weathered argillaceous shale compromised soil-like material that can be broken down by hand. The moderately weathered argillaceous shale and moderately weathered silty shale compromised rocks that can not be broken down by hand. The initial groundwater level ranged greatly in elevation, which was determined based on the limited piezometer measurements conducted several months after the slope failure. Direct shear tests were performed on core samples collected before slope excavation to obtain the shear strength parameters of the soils. The mechanical properties of the rocks were determined based on the laboratory tests and engineering experiences. Table 1 summarizes the properties of these materials.

To increase the slope stability and prevent erosion of the exposed slope surface, grid beams were installed on the surface of soil materials and mesh-reinforced shotcrete on the surface of rock materials (Fig. 4). In addition, intercepting ditches were constructed along the crest of the slope, with channels along the slope surface for surface-water drainage. It should be noted that after the cutting was finished, the measures (e.g., drain holes) were not adopted immediately for draining underground water behind shotcrete facings.

\section{Failures Of The Slope}




\subsection{Failure of the cut-slope}

About three months after the excavation was finished, the study area was subject to several heavy rainfalls since the $27^{\text {th }}$ of May, 2013. A landslide occurred on the $25^{\text {th }}$ of June, 2013, resulting in the deformation of the grid beams and failures of the shotcrete facings (see Fig. 5). This failure is called the first slope failure in the following context. The main sliding body was approximately $170 \mathrm{~m}$ in length, 130 $\mathrm{m}$ in width, $0.02 \mathrm{~km}^{2}$ in area, and $4.78 \times 10^{5} \mathrm{~m}^{3}$ in volume, with the direction of $347^{\circ}$ from North (Fig. $6 \mathrm{a}$ ). The average elevations of the leading and trailing edges of the landslide were $656 \mathrm{~m}$ and $739 \mathrm{~m}$, respectively. Moreover, there were numerous tension cracks in the upper part of the slope.

Field observation and borehole investigation after landslide revealed that there were two sliding surfaces and the thickness of the sliding mass ranged from $9 \mathrm{~m}$ to $22 \mathrm{~m}$ (see Fig. 6b). The shallow sliding surface was mainly within the pebbly silty clay layer, with part of the surface along the surface of the strongly weathered argillaceous shale layer. The deeper slip surface initiated in the top layer and extended into the second layer. The material of slip zone in the deep failure surface mainly was the strongly weathered argillaceous shale. The weak layers (i.e., mudstone interlayers which will be discussed later) developed in the strongly weathered shale layer could contribute to the formation of the deep slip surface due to the softening of the mudstone under rainfall. However, this condition was not appropriately recognized after the slope failure. The field investigation also found that groundwater flowed out of the slope along the fissures of shotcrete facings. This indicates that high water pressure had been built up in the slope due to the blockage of natural seepage by the shotcrete and the absence of subdrainage system, e.g., horizontal drain hole and drain tunnel, as recommended in the Chinese Standard (GB50330-2013) and Sun et al. (2010b). The movement of the sliding mass gradually stabilized in October 2013.

\subsection{Remediation of the failed cut-slope}

To avoid further sliding in the next rainy season, the slope at elevations between $636 \mathrm{~m}$ and $726 \mathrm{~m}$ was reinforced with fully-grouted anchors, anchor cables and grid beams. The material parameters listed in Table 1 were used in the original reinforcement design. The detailed plan view of reinforcement scheme of the failed slope is shown in Fig. 7. Firstly, excavations were performed at elevations of $706 \mathrm{~m}$ and 716 $\mathrm{m}$ to reduce the loading. Then anchor cables and grid beams were installed in the upper and middle sections of the slope and anchors were installed in the lower part of the slope. A detailed cross section of the reinforced slope can be seen in Fig. 10.

The reinforcement structures were designed based on the Chinese specification (DZ/T 0219-2006) to meet the requirement of safety factor for the cut-slope. The anchor cable was made up of five prestressed high-strength steel strands. The ultimate capacity of each cable was $1300 \mathrm{kN}$. The anchor cables were inclined at an angle of $25^{\circ}$ and spaced on a $2 \mathrm{~m}$ to $3 \mathrm{~m}$ by $2.5 \mathrm{~m}$ grid, with a total length of $17 \mathrm{~m}$ to $36.5 \mathrm{~m}$ depending on their locations. They were installed in $130 \mathrm{~mm}$ diameter bore holes, with the bonded length of $8.5 \mathrm{~m}$. Each cable anchored to the grid beams at the slope surface was prestressed to the tensile force of $520 \mathrm{kN}$. All of the grid beams with the cross section of $400 \mathrm{~mm} \times 450 \mathrm{~mm}$ were 
fabricated using C30 concrete (with the compressive strength of $30 \mathrm{MPa}$ ). Fully-grouted anchors were installed on a $2.0 \times 2.0-\mathrm{m}$ grid using 28-mm-diameter, 6-m-long HRB400 steel bars in $75 \mathrm{~mm}$ diameter bore holes at the inclination angle of $15^{\circ}$.

After the construction of the reinforcement structures, the exposed slope surface was covered with shotcrete on rock surface to prevent weathering and erosion. The drainage holes with spacing of $4 \mathrm{~m}$ in both vertical and horizontal directions and nominal diameter of $75 \mathrm{~mm}$ were installed on the shotcrete facings to drain the ground water. The ditches were built surrounding the landslide to intercept the surface water and the channels were constructed for surface drainage. The whole construction was finished in early July 2014 .

\subsection{Failure of the remediated slope}

About two weeks after the completion of the remediation works, a second slope failure occurred on the $18^{\text {th }}$ of July, 2014 , under continuous heavy rainfall. The maximum daily precipitation recorded by a nearby weather station was $123.6 \mathrm{~mm}$ during that period. On the $21^{\text {st }}$ of July, 2014, large deformation was observed at the lower part of the reinforced slope (see Fig. 8). The slump was about $60 \mathrm{~m}$ long, $40 \mathrm{~m}$ wide and $5 \mathrm{~m}$ thick, with a total volume of approximately $9,000 \mathrm{~m}^{3}$. Further distress of the slope led to the failure of the reinforcement system, including the failure of anchor cables and grid beams (Fig. 9), the cracking of shotcrete facings, and the distortion of the channels.

Field investigation was conducted shortly after the second slope failure. The boreholes, i.e. BH3-BH6 shown in Fig. 10, revealed that two of the shallow slip surfaces were in the pebbly silty clay layer, with the slip surfaces along the contact with the strongly weathered argillaceous shale. The deeper slip surface passed through the edge of most of the anchor cables. The lower part of the deep slip surface was mainly along the interface between strongly weathered argillaceous shale layer and moderately weathered argillaceous shale layer. The boreholes, i.e. $\mathrm{BH} 1$ and $\mathrm{BH} 2$, indicated that the thickness of the weathered, well-permeable rocks ranged from 40 to $60 \mathrm{~m}$, which was favorable for the surface water to flow into the sliding mass and the accumulation of the groundwater. At the toe of the slope, several small sinkholes were observed around the axis of the syncline with water flowing out of the holes. This suggests that high pore water pressure had been built up in the lower part of the slope, possibly due to the blockage of natural seepage by the shotcrete on the slope surface and the insufficiency of drain holes. According to the water levels measured from the boreholes, the groundwater table after the heavy rainfall rose by $2-10 \mathrm{~m}$ (Fu et al., 2017).

After the site investigation, the soil samples collected from the boreholes were used to perform the laboratory tests. The tests results revealed that the shear strength of the materials from the top two layers decreased, as compared Table 1 to Table 2. In particular, the cohesion and friction angle of the strongly weathered argillaceous shale almost halved. The possible reason is that the strongly weathered argillaceous shale layer contains abundant mudstone interlayers. In particular, two weak mudstone layers were discovered in this field investigation (Fu et al., 2017). These two weak layers: one with the thickness 
of 5-10 cm, the length of about $30 \mathrm{~m}$ and dip angle of $15^{\circ}$ towards the slope surface, and the other with the thickness of $5-15 \mathrm{~cm}$, the length of about $50 \mathrm{~m}$ and dip angle of $10^{\circ}$ towards the slope surface, developed within the strongly weathered argillaceous shale layer. The weak mudstone layers have a detrimental impact on the slope stability. In the first laboratory tests, the samples obtained from boreholes did not contain the weak material, but in the second laboratory tests, the weak layers were discovered and considered in the determination of the mechanical parameters. The mudstone tends to soften and slake when wetted, resulting in the significant decrease of shear strength (Liu et al., 2000; Wang et al., 2009; Zhang et al., 2016). Moreover, the construction of anchor cables may disturb the strongly weathered argillaceous shale, and hence further contribute to the decrease of its strength.

\section{Finite Element Analyses}

To investigate the failure mechanism and causes, the slope was analyzed using the two-dimensional finite element program, PLAXIS, Version 8.2. The cross section BB' shown in Fig. 10 was used to analyze the slope stability. The size of numerical model was $395 \mathrm{~m}$ in length and $176 \mathrm{~m}$ in height. The bottom boundary was fixed in both horizontal and vertical directions, and the side boundaries were fixed horizontally but free to move vertically. Fig. 11 presents the numerical model of the slope with the fullygrouted anchors, anchor cables and grid beams. The 15-node triangular element was used in the numerical model, which includes 860 elements and 7113 nodes, with very fine meshes. The initial stress field of the slope was obtained using the gravity loading procedure. Hydrostatic water condition was considered in the analyses.

The soil and rock were modeled with the linear elastic-perfectly plastic Mohr-Coulomb model. The nod-tonod anchor element and the geogrid element were used to simulate free section and bond section of the anchor cable, respectively, as recommended in PLAXIS manual. The elastoplastic model was employed for both the anchor element and geogrid element. Since the anchor cables were prestressed to $520 \mathrm{kN}$, the mean horizontal spacing of anchor cables was $2.5 \mathrm{~m}$, thus a $208 \mathrm{kN} / \mathrm{m}$ prestress load was applied to the anchor cables. The fully-grouted anchors were modelled with the geogrid element using the linear elastic model. The grid beams were simulated with plate element using the linear-elastic model. The physical and mechanical parameters of the anchors, anchor cables and grid beams in the numerical model are summarized in Table 3.

Stability analysis in PLAXIS code is performed using the strength reduction method, where shear strength parameters $\varphi$ and $c$ are reduced by the same ratio until equilibrium state is reached (Brinkgreve et al., 2004):

$$
F S=\frac{c}{c_{r}}=\frac{\tan \varphi}{\tan \varphi_{r}}=\sum M_{s f}
$$

where $F S$ is the factor of safety; $c_{\mathrm{r}}$ and $\varphi_{\mathrm{r}}$ are the reduced cohesion and friction angle, respectively; $\Sigma M s f$ is the total multiplier, which is increased in a step-by-step procedure until failure occurs. 


\subsection{Analyses of the first slope failure}

To investigate the cause of the first landslide, the stability of the cut-slope was analyzed considering two scenarios: under natural conditions (initial groundwater level), and under extreme rainfall conditions (water level close to the ground surface). Due to the uncertainty of groundwater level during the first slope failure, the effect of the heavy rainfall on slope stability was modeled by applying the different water levels. It should be noted that the assumed extreme rainfall condition was implemented by increasing groundwater level until the slope reached the limit state. The reinforced structures were set to be in a nonactivation state (grey state in the numerical model) to simulate the slope without reinforcement. The parameters listed in Table 1 were used in this analysis.

As shown in Fig. 12a, under natural water table condition, the slope after excavation has a FS value of 1.22 , and the potential slip surface lies in the limited zone of upper part of the slope. However, under extreme rainfall condition (see Fig. 12b), the critical slip surface enlarges and propagates upwards because of the rising of ground water, and the FS value of the slope reduced to 1.01, which is at limit state. This means that the cut-slope was certainly stable under natural condition, but it failed under heavy rainfall. In Fig. 12b, the predicted failure surface develops along the contact of top layer and second layer and lies in between the investigated ones. It can be inferred that the failure might have been induced by the rapid increase of pore water pressure within the slop after long-lasting rainfall, even though the numerical model only predicted one slip surface. It is worth noting that, the lower part of the slope surface was covered with shotcrete but the drain holes were not installed in this part, which have blocked the drainage of the slope and resulted in the high pore water pressures in the local part of the slope. This situation may mainly cause the occurrence of deep slip surface observed in the field. However, the pore pressure distribution in the field is not simulated accurately in the numerical modeling (Liu et al., 2012). Therefore, the assumed water table in the model may be unrealistic and is only for simplicity. Also, the recharge of water from the gully (R3), could make the water regime in the slope more complicated than the one assumed in the numerical model.

For comparison, the stability analysis of the slope before excavation was also conducted using the FEM. The results show that the FS values of the slope are 1.29 under natural conditions and 1.06 under extreme rainfall conditions. As compared to the analytical results after excavation (i.e., 1.22 under natural conditions and 1.01 under extreme conditions), the difference of the FS between them is relatively small. This is due to the fact that potential slip surface only develops within the top soil layer and the shear outlet is mainly along the contact between the first layer and the second layer, which are very similar to that shown in Fig. 12. The excavation was performed to mainly cut the second to fourth rock layers, which has minimal effect on the resistance to the upper sliding mass. It should be mentioned that the FS value of the slope without excavation is 1.06 under extreme conditions, which does not indicate that the natural slope under this condition is absolutely stable. The instability of the slope is likely to occur or the slope is at limit state, even under the calculated FS larger than 1.0. However, before excavation the slope in the field is very stable all the time. In this case, the calculated FS may be less than the actual FS of the slope without any construction activities. 
The cutting at the toe of the slope may have resulted in the expansion of cracks and fissures in the strongly weathered argillaceous shales. This may have further increased the seepage of water into the cracks and weakened the soil in the shale layer. As indicated by Lee et al. (1996), many forms of geologic damage such as erosion and slope failure could occur in the mudstone formation when wetted under rainfall. After investigating the slope failures in southwestern Taiwan, Lee et al. (2007) found that failure rate in mudstone slopes is the highest among all rock types. Since there were no data available, this factor is not considered in this analysis, but will be considered in the second slope failure.

\subsection{Analyses of the second slope failure}

Firstly, stability of the reinforced slope under extreme rainfall conditions was analyzed using the parameters listed in Table 1, which were used in the original remediation design. The result from Fig. 13 shows that the potential slip surface of the reinforced slope mainly develops within the third rock layer (i.e., moderately weathered argillaceous shale layer). The slope is stable, with the FS value of 1.11. This suggests that provided the strength of slope materials was not decreased owing to the rainfall and excavation, the reinforced slope could be stable even under extreme rainfall conditions.

However, the laboratory tests after the second slope failure revealed that the strength parameters of the weathered shale layer reduced dramatically. As discussed earlier, the mechanical strength of the mudstone interlayers would reduce when wetted, especially after being wetted and disturbed by the construction of anchor cables. This factor might not be properly recognized in the original remediation design of the slope after the first failure. To consider this factor, the reinforced slope was reanalyzed by using the shear strength parameters listed in Table 2 and keeping other parameters identical to that listed in Table 1.

In the analysis, different heights of groundwater table were considered to obtain the relationship between the safety factor of the slope and the groundwater level. The results in Fig. 14 show that the slope stability decreases with rising of groundwater level. Under natural water table condition, considering the reduction of soil strength, the FS of the reinforced slope is about 1.12. But the slope would have failed when water table increases by $7 \mathrm{~m}$. This value is very close to the mean increment of water level revealed from the site investigation as described in Section 4.3. As shown in Fig. 15, the critical slip surface of the slope with an elevated water level passes through the ends of anchor cables, indicating a global failure. The computed slip surface is very close to the deep failure surface revealed from the site investigation as described earlier. This indicates that the second slope failure was partly due to the heavy rainfall, and partly due to improper design of the anchor cables.

Again the assumption of the water table used in this analysis is an ideal shape. As reported by Sun et al. (2013b), localized slump could change the water flow in a slope and cause a second landslide. The first landslide may have changed the water flow path in the second layer. During the site investigation after the landslides, this issue was not considered, and therefore this factor can not be confirmed. Investigation on this issue is strongly recommended before adopting any further remediation measures. 


\subsection{Discussion}

In the first design, grid beams and shotcrete were installed on the slope surface to improve the slope stability and protect the exposed slope surface from erosion. However, this reinforcement system had very limited effect on the global stability of the slope. During rainy season, the rain water from the gully on the top corner of slope could easily infiltrate into the upper part of the slope and then flow into the lower part of the slope through the strongly weathered, highly permeable rocks revealed after the second slope failure. The application of shotcrete on the highly fissured rock surface could have blocked the natural drainage of ground water out of the slope, without installing horizontal drain holes immediately. This could have caused the rapid rise of water table and high pore pressure in the local part of the slope. In addition, two weak mudstone interlayers were revealed by excavation, but were not considered in the design. The shear strength of slope materials was reduced due to the transient high water pressure and softening of mudstone interlayers, thus triggering the first slope failure.

After the first failure, the remedial works were performed without proper understanding of the soil properties. The reduction of soil strength, especially strongly weathered argillaceous shale layer, and the two weak interlayers might not be appropriately recognized. The adoption of the soil shear strengths overestimated the stability of the reinforced slope. In fact, the natural drainage of ground water was blocked, possibly due to the first landslide and the application of shotcrete on the slope surface. Moreover, the drain holes were insufficient to completely dissipate the raised ground water during heavy rainfall. These could have caused the rapid rise of groundwater level within the slope, increased the weight of the sliding mass, and reduced the shear strength of materials along the potential sliding surface (Song and Cui, 2016). Therefore, the stability of the reinforced slope decreased significantly. In addition, the anchor cables were installed in the weak rock layer, and did not provide enough resisting forces to the slope under rainfall. These factors could have caused the second failure only few days after the remediation. The global failure of the slope, i.e. the deeper slip surface, resulted in the great loss of reinforcement effect of the anchor cables. The instability of the lower sliding mass could trigger the movement of upper section of the slope (Song and Cui, 2016), i.e., another two shallow sliding bodies shown in Fig. 10. Since once loosened, unlike the fully grouted anchors, the anchor cables can not provide any resistance for overall stability of the slope.

Overall, heavy rainfall was a major factor that induced the initial landslide and the subsequent slope failure. In addition to rainfall, several other influence factors triggered the slope instability. The adverse geological conditions such as weak interlayers and improper subdrainage system had harmful impact on the stability of the slope. The heavy rainfall infiltration through the strongly weathered, highly permeable rocks resulted in the increase of transient water pressure and decrease of shear strength of materials. Insufficient geological and hydrogeological investigation contributed to the instability of engineered slope and misled remedial works. Therefore, the design of engineered slope should be conducted not only based on the prescriptive standard but also considering the particular geological and hydrological conditions. 


\section{Recommended Remediation Method}

Based on above analysis, it was recommended to install additional longer anchor cables to the third soil layer, i.e., the moderately weathered argillaceous shale, as the deep slip surface passed through the ends of the anchor cables. Fig. 16 presents the geological profile of the slope with extended anchor cables. The bonded length of the extended anchor cables was also $8.5 \mathrm{~m}$. The strength parameters of top two layers listed in Table 2 were used in the analysis to consider the reduction of soil strength.

The results from FEM show that, the FS value of the slope with extended anchor cables is 1.55 under natural conditions, and 1.14 under extreme rainfall conditions with water table close to the slope surface. According to the Chinese specification (DZ/T 0219-2006), the required safety factors of the reinforced slope are 1.20 to 1.30 under natural conditions and 1.10 to 1.15 under rainfall conditions. Therefore, it can be considered that the extended anchor cables can significantly stabilize the sliding mass and improve the slope stability even under extreme rainfalls. The potential slip surface of the slope under this condition is presented in Fig. 17. The result shows that there are two potential slip surfaces within the slope. One develops along the contact between the strongly weathered argillaceous shale layer and moderately weathered argillaceous shale layer and the other mainly along the ends of the anchor cables. The extended anchor cables expand the slip surface and pass through shallow slip surface, and thus improve the stability of the slope.

\section{Summary And Conclusions}

A cut-slope located in the northeastern part of Sichuan Province, China failed twice after the cutting at the toe of the slope. The first failure was about three months after the cutting, and the second failure was a few days after the remediation using anchor cables and grid beams. Both failures were closely related to the heavy rainfall. Finite element analyses incorporating the shear strength reduction method were performed on the slopes using several assumptions based on the available information to find out the possible causes and failure mechanisms of the landslides. Based on the field investigations and numerical analyses, the following conclusions can be drawn:

(1) The correct understanding to the geological conditions is vital to the slope engineering. However, during the initial site investigation, the adverse geological condition was not appropriately recognized. The weak interlayers embedded in the strongly weathered argillaceous shale were not discovered initially but were revealed by following excavation, which have detrimental effect on the stability of the cut-slope under rainfall. The combined effects of the excavation and heavy rainfall trigger the first slope failure.

(2) The rapid rise of the groundwater level during heavy rainfall immersed the part of strongly weathered rock layer and thus decreased the shear strength of materials. However, the nature of the strongly weathered shale layer with cracks, fissures and weak interlayers were not properly considered in the original design. Ignoring the softening of strongly weathered rock with weak layers was the likely primary cause of the improper remediation design. These factors contribute to the second slope failure. 
Significant attention should be paid to the characteristics of weathered rocks, especially with weak interlayers, before any cuttings and stabilization works.

(3) Shotcrete were installed on slope surface to avoid erosion and weathering, but the shotcrete may have blocked the natural drainage of ground water out of the slope, resulting in the high pore water pressure within the slope and hence reducing the slope stability. Therefore, an appropriate drainage system is essential to dissipate ground water during heavy rainfall. Moreover, the construction of reinforcing measures as well as drainage system (e.g., horizontal drain holes or underground drainage tunnel) should be performed as early as possible, following the slope excavation.

(4) The improper recognition to the weathered rock layer also led to the wrong application of remediation measures. The bond sections of most of the anchor cables were constructed in the weak rock layer, i.e., the strongly weathered argillaceous shale layer. This resulted in the insufficiency of resisting force to the sliding mass after softening of the strongly weathered rock under heavy rainfall. To ensure the overall stability of the cut-slope, anchor cables should be extended to the strong rock layer without weak planes.

(5) In many civil projects, understanding of site condition and soil properties have not been properly considered as it should be, partly due to the limitation of time or the lack of funding. It is learned from this case study that all the parties involved in projects should pay big attention to the geological, hydrological and geotechnical properties of the site, especially for the slope under complex geological conditions. A comprehensive analysis based on the site investigation information is essential to the slope design.

\section{Declarations}

\section{Acknowledgments}

This work was supported by the National Key Technologies Research and Development Program of China (No. 2019YFC1509702), and the National Natural Science Foundation of China (No. 41602287).

\section{Author Contributions}

All authors contributed to the study conception and design. All authors commented on previous versions of the manuscript. All authors read and approved the final manuscript.

Site investigation: Jianfeng Chen and Qingzhao Zhang;

Writing - original draft preparation: Jianfeng Chen and Xiaopeng Guo;

Writing - review and editing: Changcheng Du, Jianfeng Xue, and Boan Jang;

\section{Declaration of Competing Interest}


The authors have no relevant financial or non-financial interests to disclose.

\section{References}

1. Brinkgreve R-B-J, Broere W, Waterman D (2004) Plaxis Version 8 Reference Manual. Plaxis BV, Delft,.

2. Barla G, Antolini F, Barla M (2013) Slope stabilization in difficult conditions: the case study of a debris slide in NW Italian Alps. Landslides 10, 343-355.

3. Bi J-F, Luo X-Q, Zhang H-T, Shen H (2019) Stability analysis of complex rock slopes reinforced with prestressed anchor cables and anti-shear cavities. Bull. Eng. Geol. Environ. 78 (3), 2027-2039.

4. Cai F, Ugai K (2003) Reinforcing mechanism of anchors in slopes: a numerical comparison of results of LEM and FEM. Int. J. Numer. Anal. Meth. Geomech. 27: 549-564.

5. Chen T, Deng J-H, Sitar N, Zheng J, Liu T-X, Liu A-J, Zheng L (2017) Stability investigation and stabilization of a heavily fractured and loosened rock slope during construction of a strategic hydropower station in China. Eng. Geol. 221, 70-81.

6. Chen G-Q, Chen T, Chen Y, Huang R-Q, Liu M (2018) A new method of predicting the prestress variations in anchored cables with excavation unloading destruction. Eng. Geol. 241, 109-120.

7. Ding X-L, Sheng Q, Han J, Cheng L-K, Bai S-W (2000) Numerical simulation testing study on reinforcement mechanism of prestressed anchorage cable. Chin. J. Rock Mech. Eng. 2000, 21(2): 177-179 (in Chinese).

8. DZ/T 0219-2006. Specification of design and construction for landslide stabilization. In: National Standard of People's Republic of China in the Field of Geology and Mineral Resources. Ministry of Land and Resources of the People's Republic of China Press, Beijing (in Chinese).

9. Ersöz T, Özköse M, Topal T (2021) Effect of disturbed zone thickness on rock slope stability. Nat Hazards, 1-24.

10. Fan G, Zhang J-J, Fu X, Wu J-B, Tian H (2016) Axial force of anchor cables in slope reinforced by double-row anti-slide piles and pre-stressed anchor cables. Chin. J. Geotech. Eng. 38 (6), 1095-1103 (in Chinese).

11. Fu X, Zhang J-J, Liao W-M, Cao L-C, Fan G (2017) Shaking table test on seismic response of slopes reinforced by pile-cable retaining structure. Chin. J. Rock Mech. Eng. 36 (4), 831-842 (in Chinese).

12. GB50330-2013. Technical code for building slope engineering, Ministry of Construction of the People's Republic of China, Beijing (in Chinese).

13. Huang R-Q (2009) Some catastrophic landslides since the twentieth century in the southwest of China. Landslides 6 (1), 69-81.

14. Huang M, Wang H, Sheng D, Liu Y (2013) Rotational-translational mechanism for the upper bound stability analysis of slopes with weak interlayer. Comput. Geotech. 53(13):133-141.

15. Jeng C-J, Chen Y-C (2013) Investigating the performance of ground anchor through the failure slope disaster in Taiwan. In: Seventh international conference on case histories in geotechnical engineering, Chicago, vol. 3, pp. 1-10. 
16. Jiang Q-H, Qi Z-F, Wei W, Zhou C-B (2015) Stability assessment of a high rock slope by strength reduction finite element method. Bull Eng. Geol. Environ. 74:1153-1162.

17. Kazeev, A., \& Postoev, G. (2017). Landslide investigations in Russia and the former USSR. Nat Hazards, 88(1), 81-101.

18. Lee D-H, Tien K-G, Juang C-H (1996) Full-scale field experimentation of a new technique for protecting mudstone slope, Taiwan. Eng. Geol. 42 (1), 51-63.

19. Liu C-W, Lu S-L (2000) Research on mechanism of mudstone degradation and softening in water. Chin. J. Rock Soil Mech. 21 (1), 28-31 (in Chinese).

20. Lee D-H, Yang Y-E, Lin H-M (2007) Assessing slope protection methods for weak rock slopes in Southwestern Taiwan. Eng. Geol. 91, 100-11.

21. Lee S-G, Hencher S-R (2009) The repeated failure of a cut-slope despite continuous reassessment and remedial works. Eng. Geol. 107 (1), 16-41.

22. Liu C-N, Yang K-H, Ho Y-H, Chang C-M (2012) Lessons learned from three failures on a high steep geogrid-reinforced slope. Geotext. Geomembr. 34, 131-143.

23. Li Z-Q, Oyediran I-A, Tang C, Hu R-L, Zhou Y-X (2014) FEM application to loess slope excavation and support: case study of Dong Loutian coal bunker, Shuozhou, China. Bull. Eng. Geol. Environ. 73 (4), 1013-1023.

24. Li C-D, Wu J-J, Wang J, Li X-K (2016) Layout and length optimization of anchor cables for reinforcing rock wedges. Bull. Eng. Geol. Environ. 75 (4), 1399-1412.

25. Lin Y-L, Li Y-X, Yang G-L, Li Y (2017) Experimental and numerical study on the seismic behavior of anchoring frame beam supporting soil slope on rock mass. Soil Dyn. Earthq. Eng. 98: 12-23.

26. Li D-Q, Masoumi H, Saydam S, Hagan P-C, Asadizadeh M (2019) Parametric study of fully grouted cable bolts subjected to axial loading. Can. Geotech. J. 56: 1514-1525.

27. Ma K, Tang C-A, Liang Z-Z, Zhuang D-Y, Zhang Q-B (2017) Stability analysis and reinforcement evaluation of high-steep rock slope by microseismic monitoring. Eng. Geol. 218, 22-38.

28. Sun H-Y, Wong L-N-Y, Shang Y-Q, Lü Q, Zhan W (2010a) Systematic monitoring of the performance of anchor systems in fractured rock masses. Int. J. Rock Mech. Min. Sci. 47 (6), 1038-1045.

29. Sun H-Y, Wong L-N-Y, Shang Y-Q, Shen Y-J, Lü Q (2010b) Evaluation of drainage tunnel effectiveness in landslide control. Landslides 7, 445-454.

30. Sun H-Y, Zhao Y, Shang Y-Q, Yu Y, Zhao Q-L (2012) Deep-seated slope failures induced by inappropriate cutting in China. Rock Mech. Rock Eng. 45, 1103-1111.

31. Sun H-Y, Zhao Y, Shang Y-Q, Zhong J (2013a) Field measurement and failure forecast during the remediation of a failed cut slope. Environ. Earth Sci. 69 (7), 2179-2187.

32. Sun H-Y, Zhong J, Zhao Y, Shen S-J, Shang Y-Q (2013b) The influence of localized slumping on groundwater seepage and slope stability. J. Earth Sci. 24 (1), 104-110.

33. Song H-F, Cui W (2016) A large-scale colluvial landslide caused by multiple factors: mechanism analysis and phased stabilization. Landslides 13: 321-335. 
34. Sun H-Y, Pan P, Lü Q, Wei Z-L, Xie W, Zhan W (2019) A case study of a rainfall-induced landslide involving weak interlayer and its treatment using the siphon drainage method. Bull. Eng. Geol. Environ. 78(6), 4063-4074.

35. Wang Y-S, Wu J-F, Wei P, Wang X-X, Han L-F, Li Y-M, Ma H-Y, Shao H-T, Xu H-B (2009) Research on time effect of rock weakening by water-rock interaction of redbeds in Sichuan basin. Chin. J. Rock Mech. Eng. 28 (sup. 1), 3102-3108 (in Chinese).

36. Wang L, Hwang J-H, Luo Z, Juang C-H, Xiao J-H (2013) Probabilistic back analysis of slope failure-A case study in Taiwan. Comput. Geotech. 51, 12-23.

37. Wang, H., Tian, G., Zhao, Y., Xie, Y., Zhang, Q., Xu, A., \& Li, X. (2019). Dynamic modeling of Meiping landslide process. Nat Hazards, 96(2), 879-892.

38. Xue D-M, Li T-B, Zhang S, Ma C-C, Gao M-B, Liu J (2018) Failure mechanism and stabilization of a basalt rock slide with weak layers. Eng. Geol. 233, 213-224.

39. Yin Y-P (2011) Recent catastrophic landslides and mitigation in China. J. Rock Mech. Geotech. Eng. 3 (1), 10-18.

40. Zhang F-Y, Liu G, Chen W-W, Liang S-Y, Chen R-S, Han W-F (2012) Human-induced landslide on a high cut slope: a case of repeated failures due to multi-excavation. J. Rock Mech. Geotech. Eng. 4 (4), 367-374.

41. Zhang S, Xu Q, Hu Z (2016) Effects of rainwater softening on red mudstone of deep-seated landslide, southwest China. Eng. Geol. 204, 1-13.

42. Zhang, F., Peng, J., Huang, X., \& Lan, H. (2021). Hazard assessment and mitigation of nonseismically fatal landslides in China. Nat Hazards, 106(1), 785-804.

\section{Tables}

Table 1 Soil properties obtained from the tests before slope excavation. 


\begin{tabular}{lllll} 
Material & $\begin{array}{l}\text { Pebbly } \\
\text { silty clay }\end{array}$ & $\begin{array}{l}\text { Strongly weathered } \\
\text { argillaceous shale }\end{array}$ & $\begin{array}{l}\text { Moderately weathered } \\
\text { argillaceous shale }\end{array}$ & $\begin{array}{l}\text { Moderately } \\
\text { weathered silty } \\
\text { shale }\end{array}$ \\
\hline $\begin{array}{l}Y_{\text {unsat }} \\
\left(\mathrm{kN} / \mathrm{m}^{3}\right)\end{array}$ & 19.5 & 21 & 23.5 & 23.5 \\
\hline $\begin{array}{l}\gamma_{\text {sat }} \\
\left(\mathrm{kN} / \mathrm{m}^{3}\right)\end{array}$ & 21 & 22 & 24 & 24 \\
\hline$C(\mathrm{kPa})$ & 37 & 96 & 120 & 298 \\
\hline$\varphi\left({ }^{\circ}\right)$ & 14 & 28.5 & 29 & 35 \\
\hline $\begin{array}{l}E_{r e f} \\
(\mathrm{MPa})\end{array}$ & 24 & 65 & 450 & 1800 \\
\hline$N$ & 0.35 & 0.3 & & 0.25 \\
\hline$k(\mathrm{~m} / \mathrm{d})$ & 2.06 & 0.18 & 0.25 & 0.058 \\
\hline
\end{tabular}

Note: $\gamma_{\text {unsat }}=$ unit weight above water table; $\gamma_{\text {sat }}=$ unit weight below water table; $c=$ cohesion; $\varphi=$ internal friction angle; $E_{r e f}=$ Young's modulus; $v=$ Poisson's ratio; $k=$ permeability coefficient.

Table 2 Shear strength parameters of the soil samples collected after the second slope failure.

\begin{tabular}{lllll} 
Material & $\begin{array}{l}\text { Pebbly } \\
\text { silty clay }\end{array}$ & $\begin{array}{l}\text { Strongly weathered } \\
\text { argillaceous shale }\end{array}$ & $\begin{array}{l}\text { Moderately weathered } \\
\text { argillaceous shale }\end{array}$ & $\begin{array}{l}\text { Moderately } \\
\text { weathered silty } \\
\text { shale }\end{array}$ \\
\hline$c(\mathrm{kPa})$ & 23 & 46 & 120 & 298 \\
\hline$\varphi\left({ }^{\circ}\right)$ & 15.5 & 19 & 29 & 35
\end{tabular}

Table 3 Input parameters for the structural elements. 


\begin{tabular}{lllll} 
Parameter & Grid beam & Anchor cable & Anchor \\
\hline & & Free section & Bond section & \\
\hline Material type & Elastic & Elastoplastic & Elastoplastic & Elastic \\
\hline$E A(\mathrm{kN})$ & $2.17 \times 10^{6}$ & $1.81 \times 10^{5}$ & - & - \\
\hline$E A(\mathrm{kN} / \mathrm{m})$ & - & - & $7.24 \times 10^{4}$ & $1.0 \times 10^{3}$ \\
\hline$E I(\mathrm{kN} \mathrm{m} / \mathrm{m})$ & $3.67 \times 10^{4}$ & - & - & - \\
\hline$N$ & 0.2 & - & - & - \\
\hline$W(\mathrm{kN} / \mathrm{m} / \mathrm{m})$ & 9.4 & - & - & - \\
\hline$L(\mathrm{~m})$ & - & 2.5 & - & 2.0
\end{tabular}

Note: $E A=$ axial stiffness; $E l=$ flexural rigidity; $w=$ unit weight; $L=$ spacing.

\section{Figures}

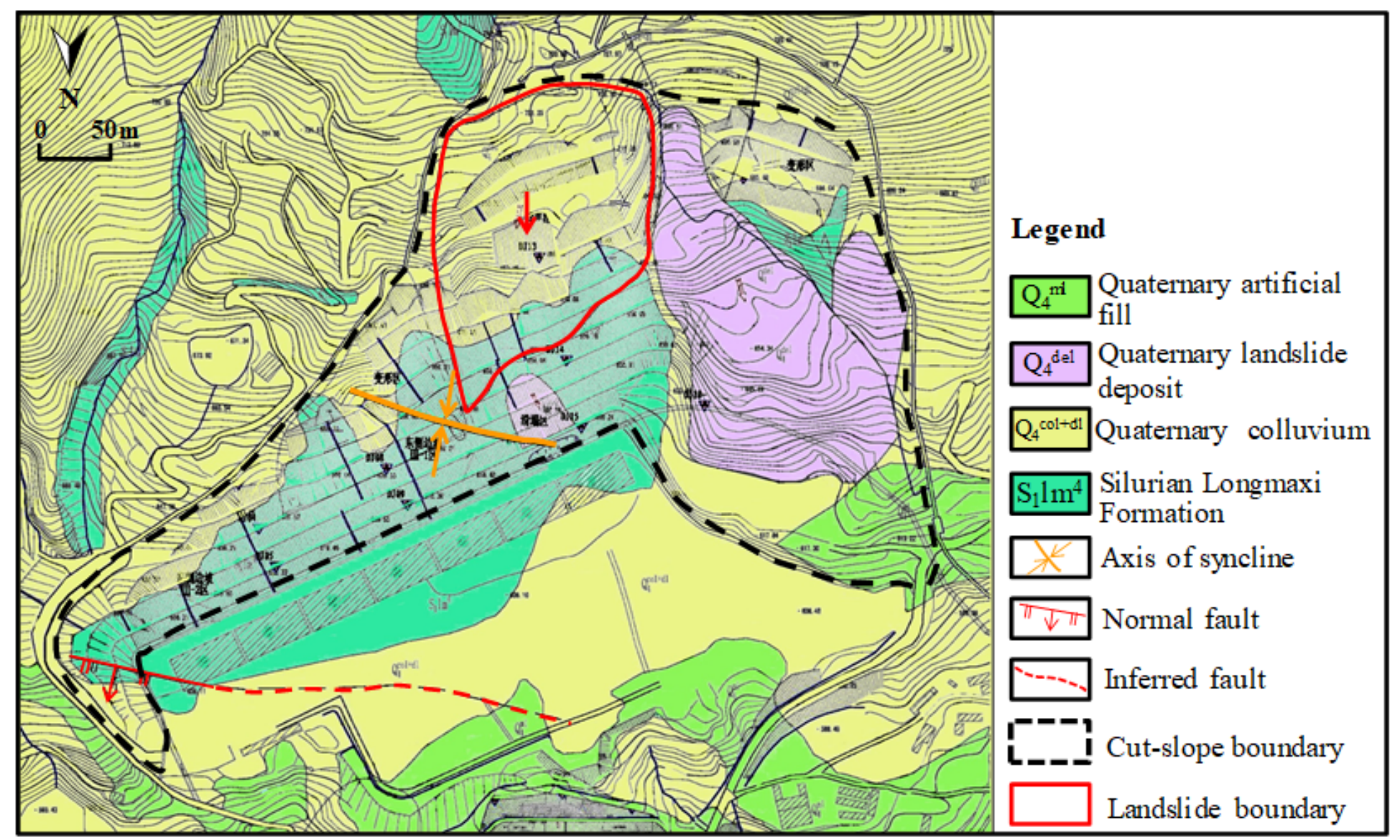

\section{Figure 1}




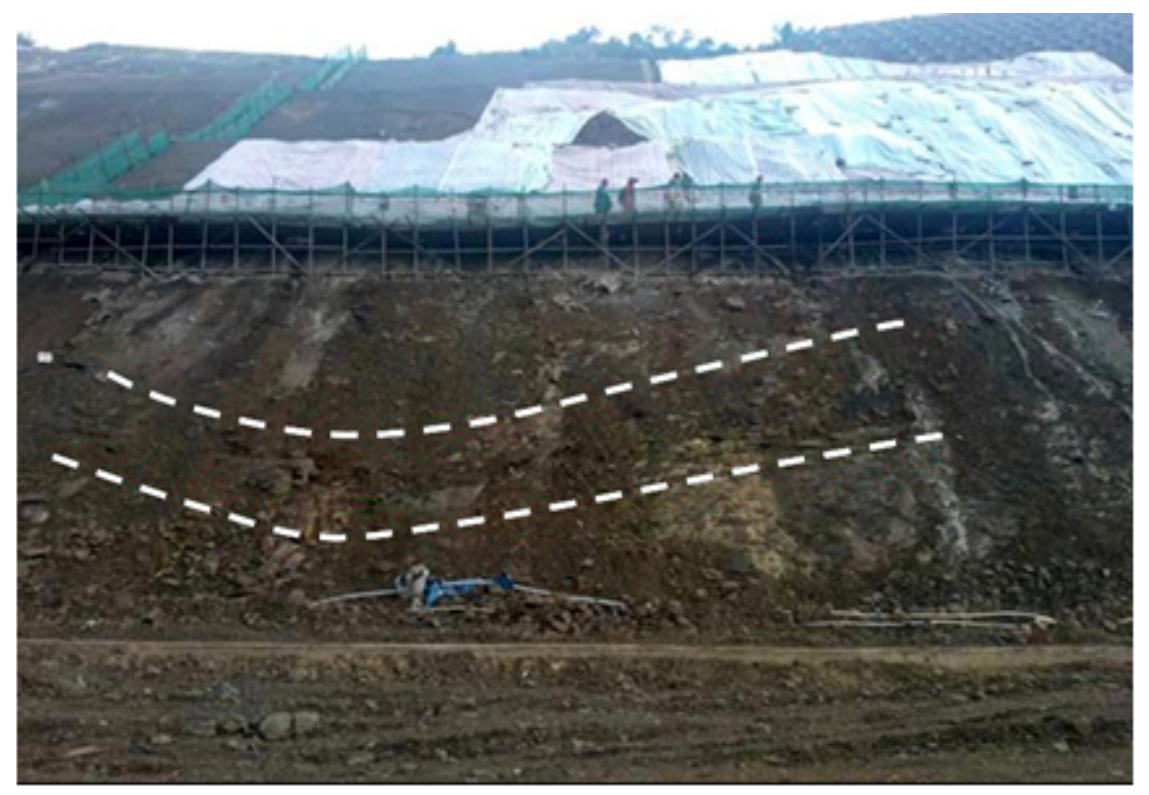

(a)

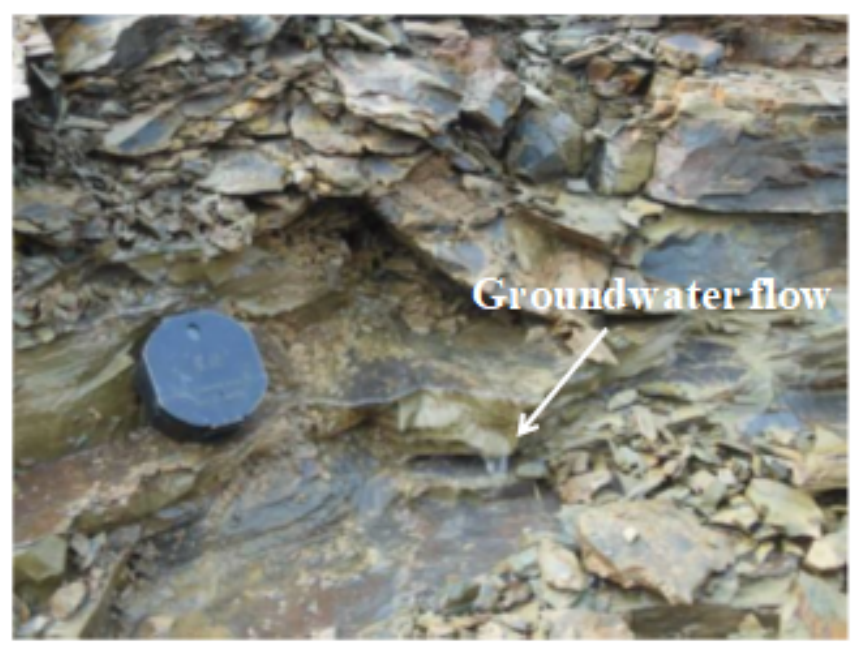

(b)

Figure 2

Photos of: $\mathbf{a}$ the core of the syncline at the slope toe; $\mathbf{b}$ the ground water flowing out of the core of the syncline after rainfall 


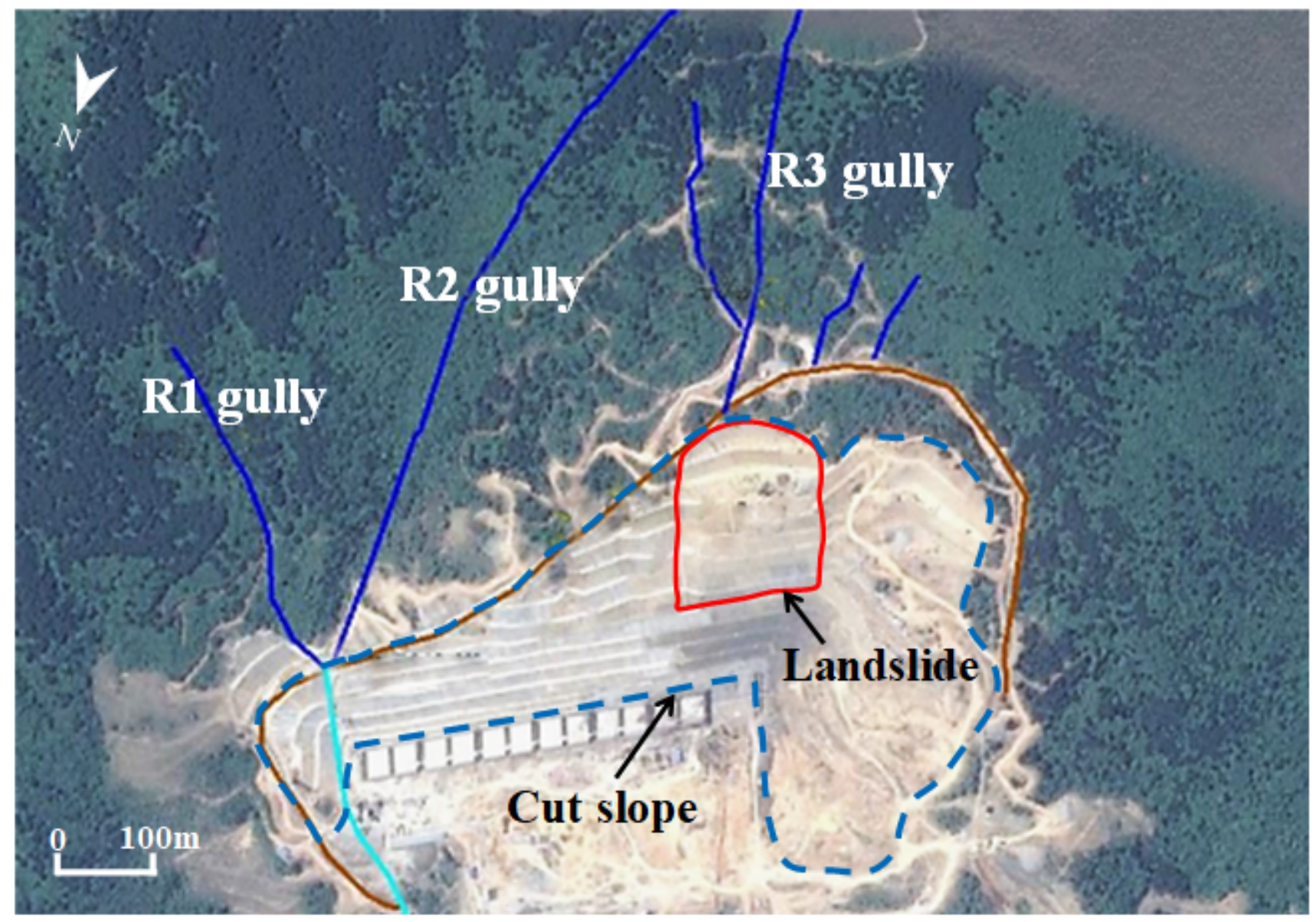

Figure 3

Gullies located above the corners of the cut-slope

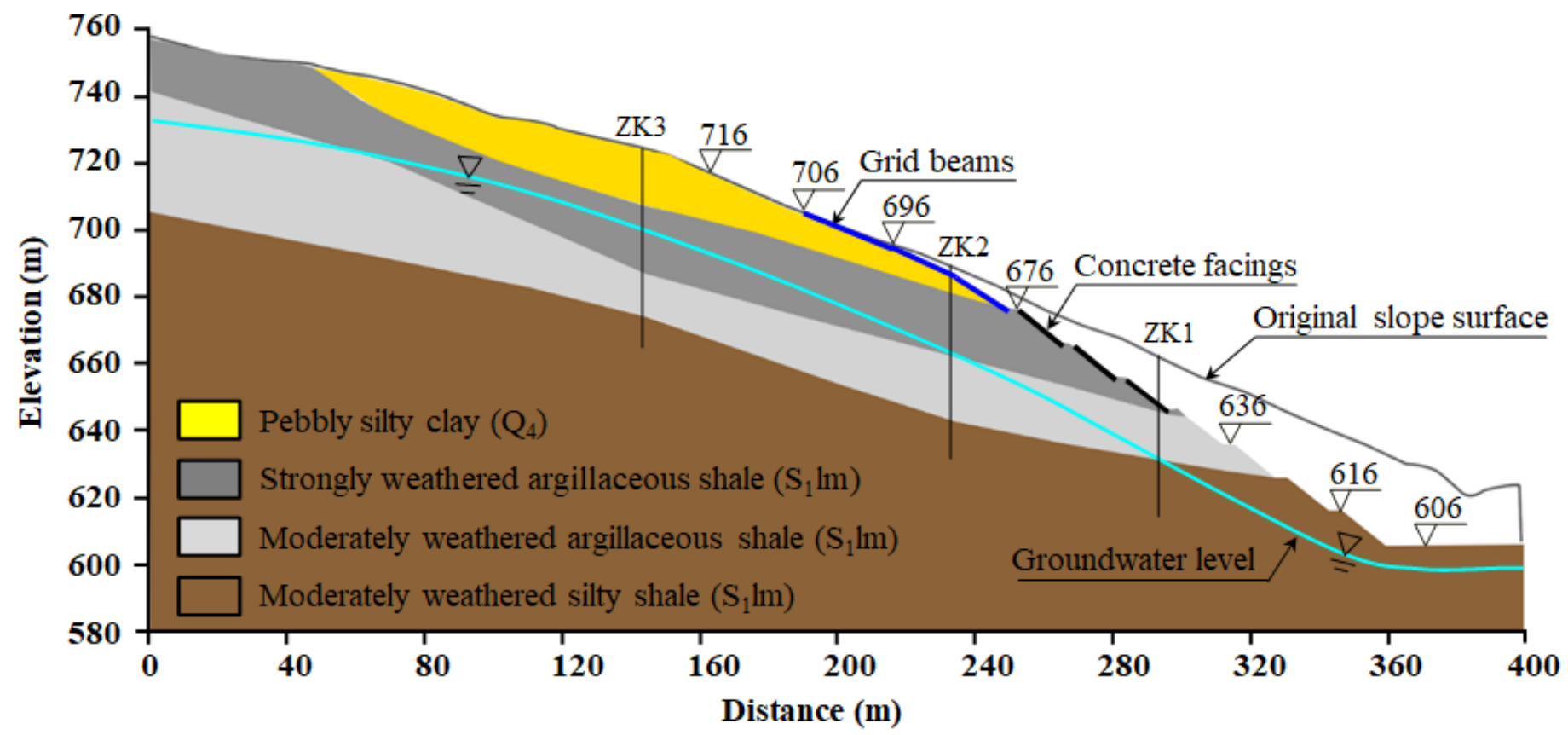

Figure 4 


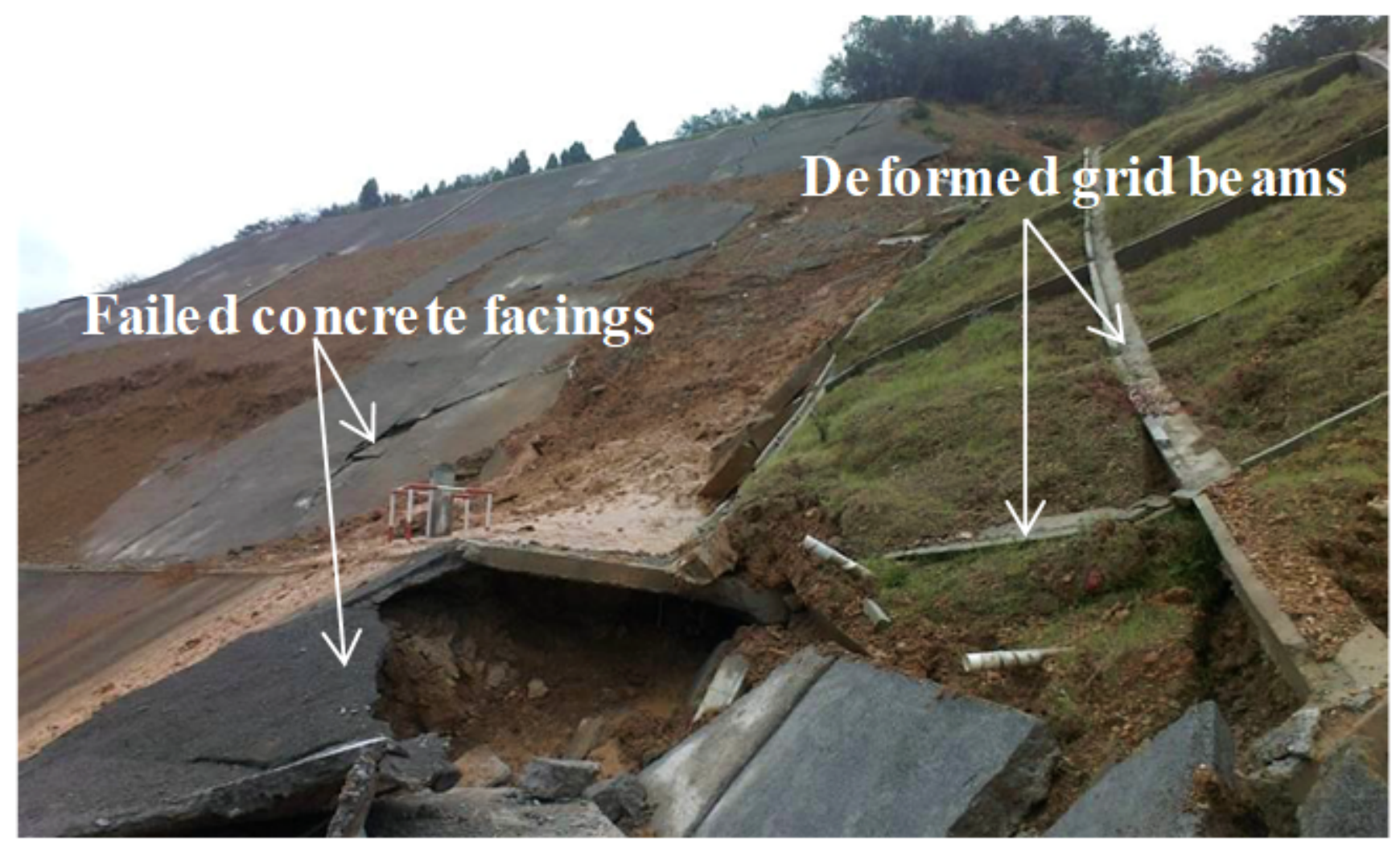

Figure 5

Photo of grid beams and concrete facings after first slope failure 


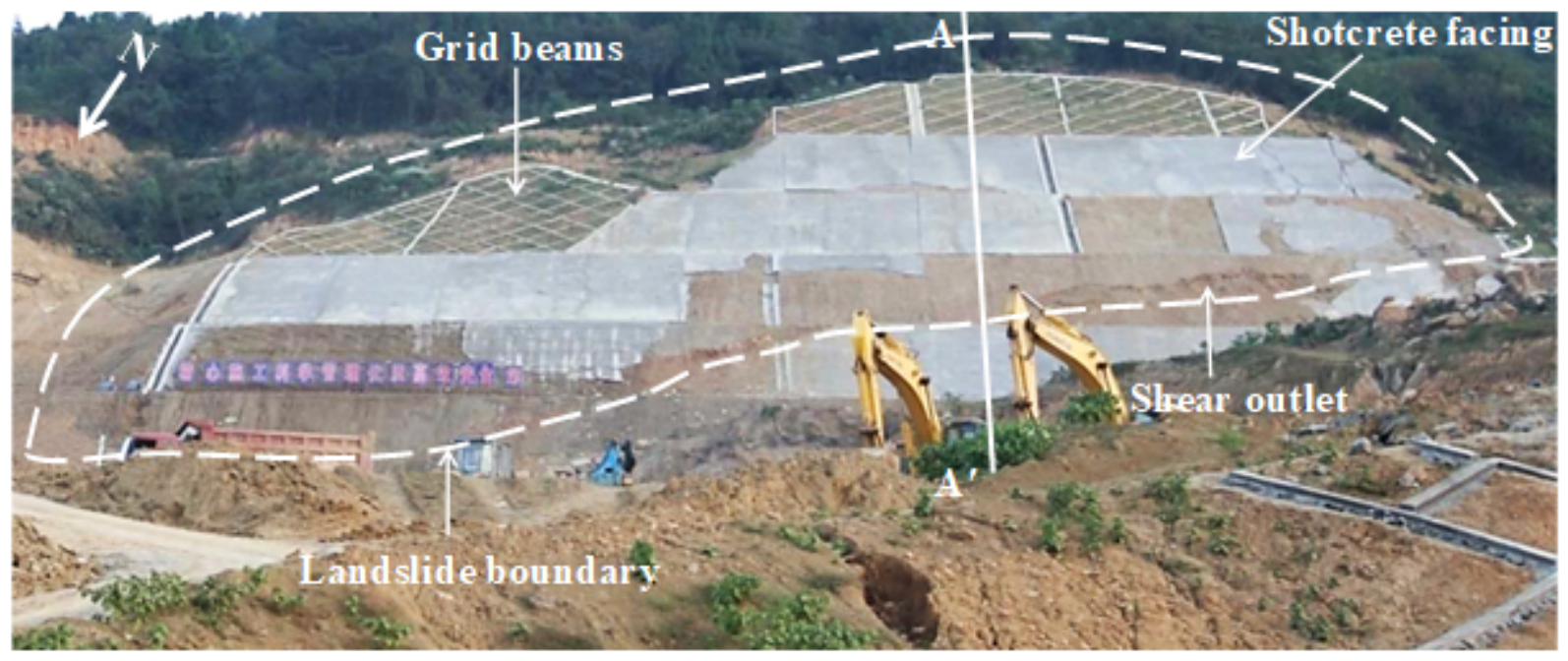

(a)

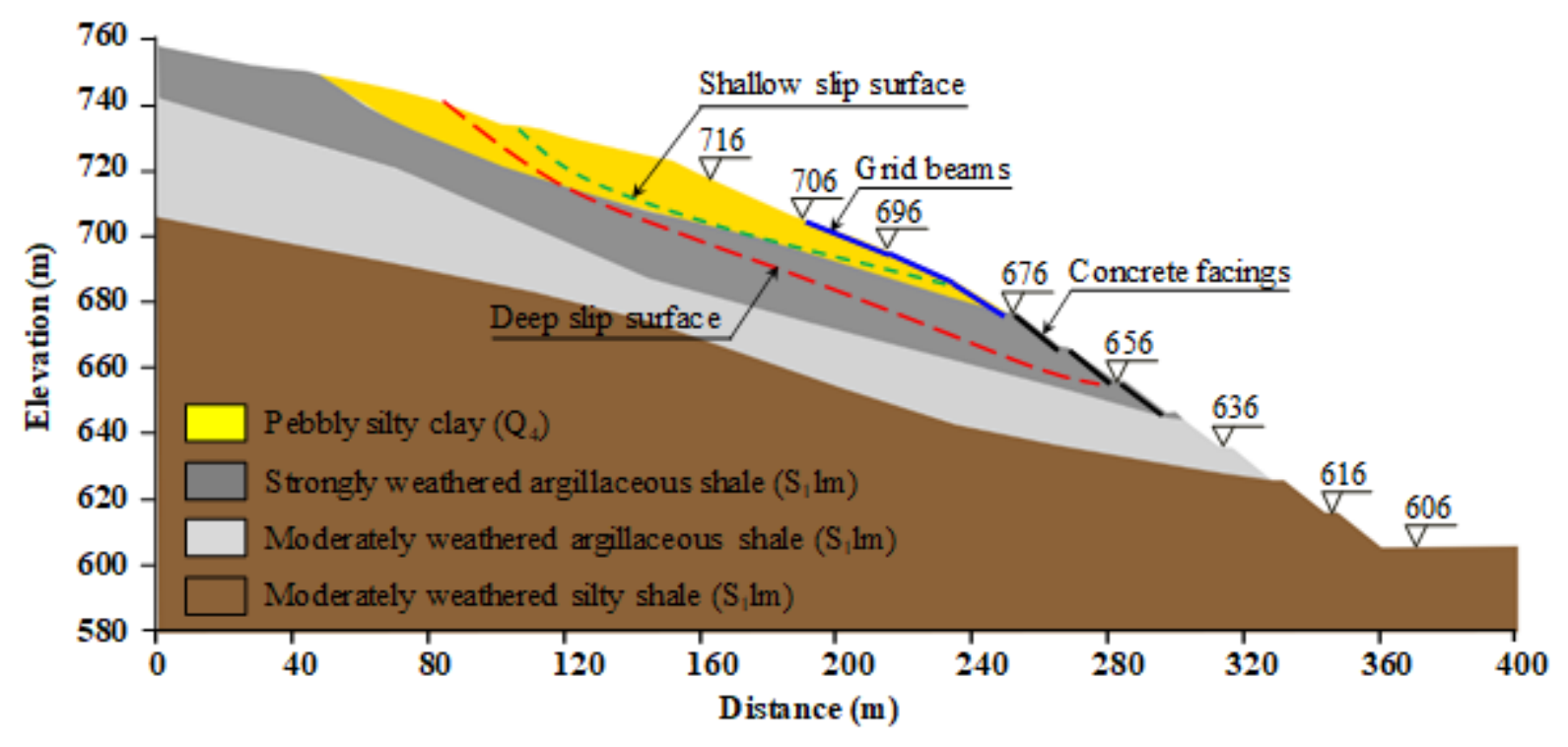

(b)

\section{Figure 6}

The first failure of the excavated slope: $\mathbf{a}$ Site photo; $\mathbf{b}$ Cross section $A A^{\prime}$ 


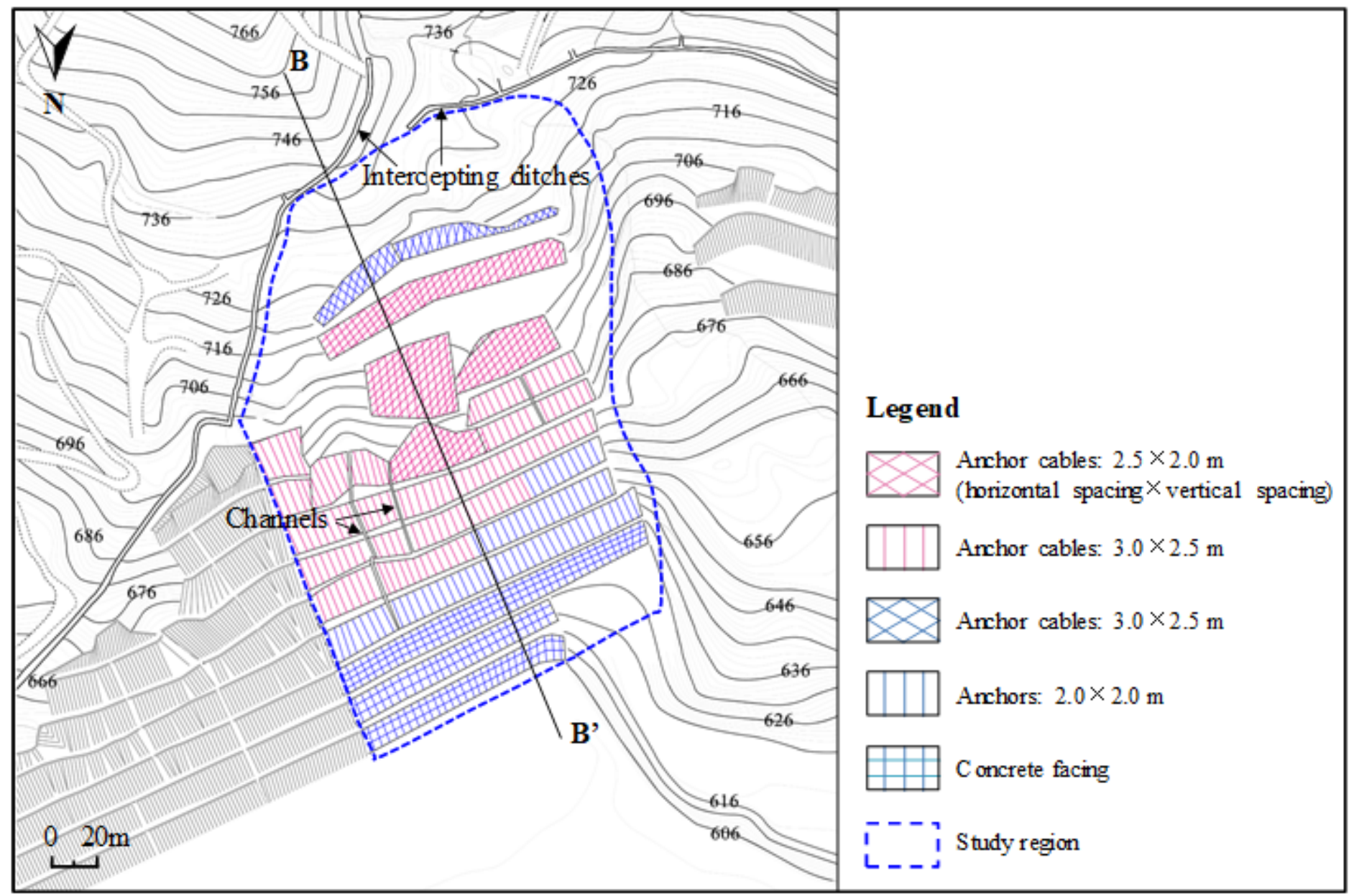

Figure 7

Plan view of the reinforced slope 


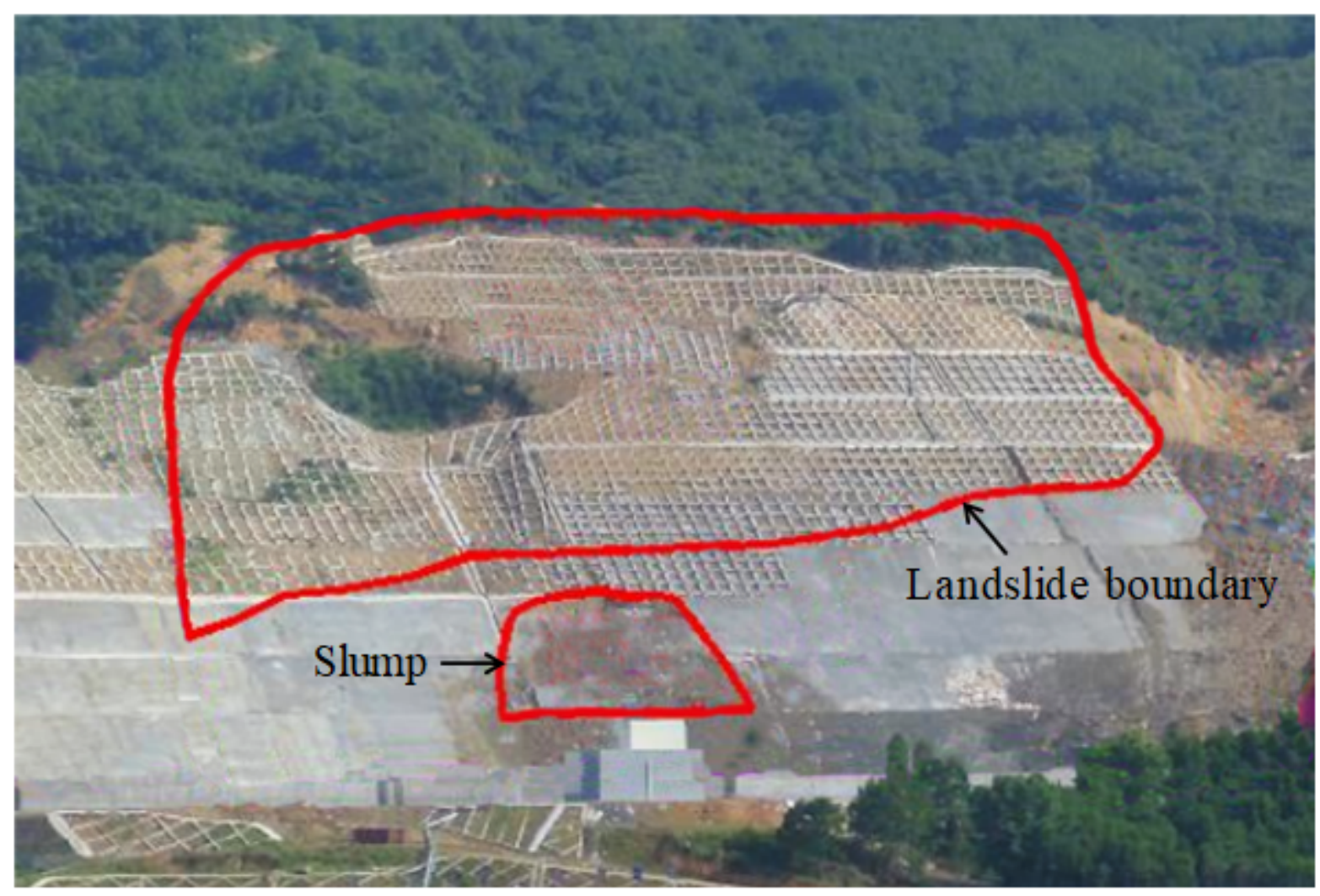

Figure 8

Site photo of the reinforced slope after the second failure

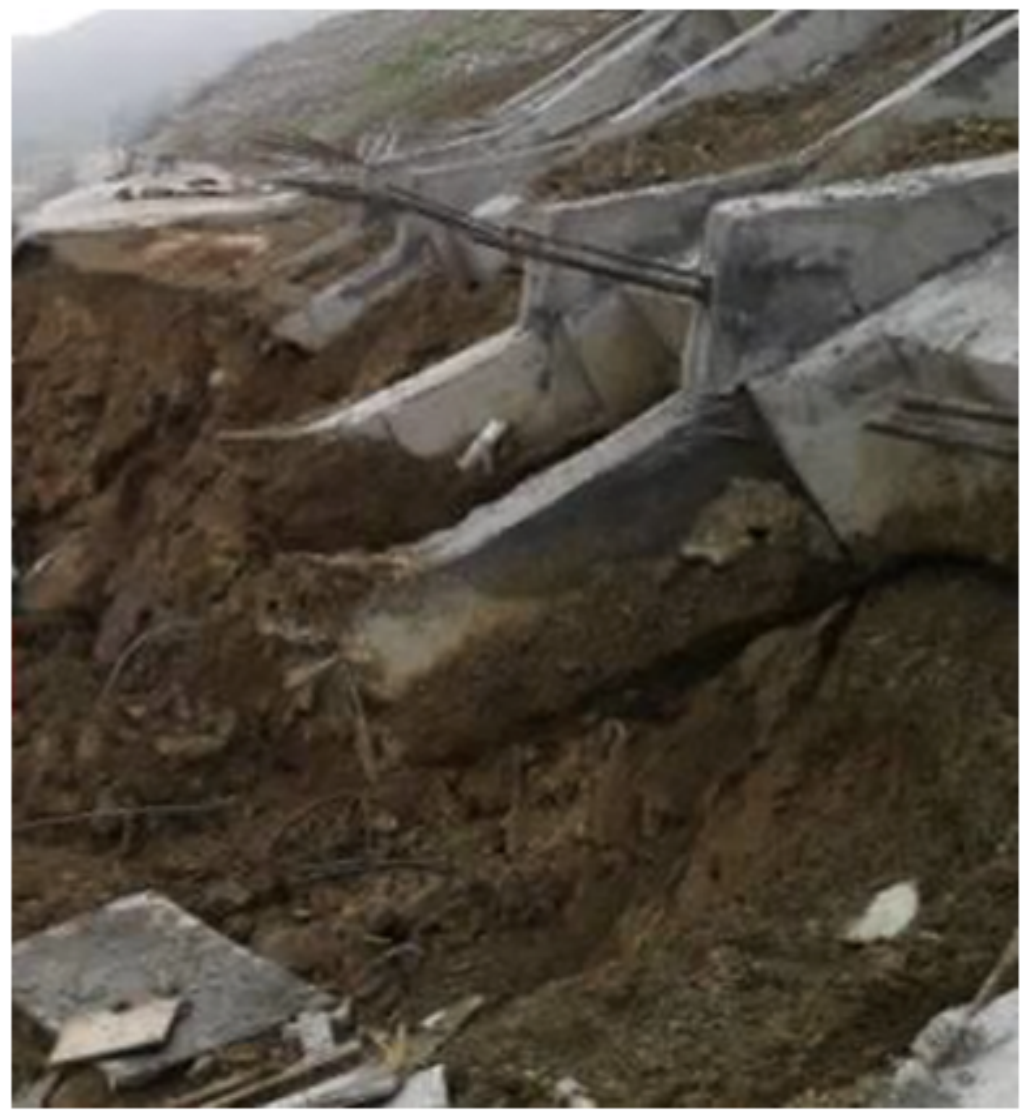

Page 23/28 
Figure 9

Photo of the failed anchor cables and grid beams

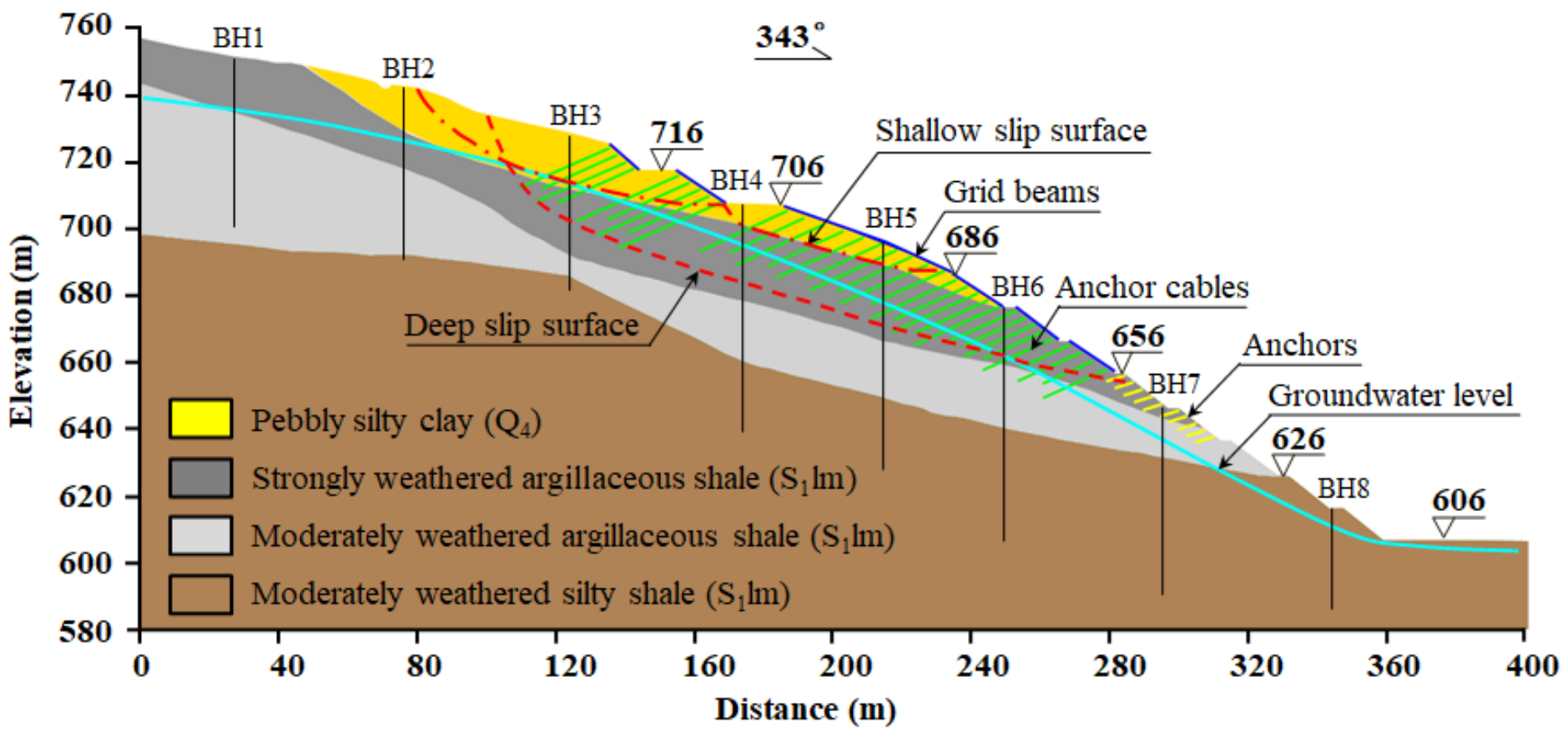

Figure 10

Cross section BB' (shown in Fig. 7) of the slope after second failure

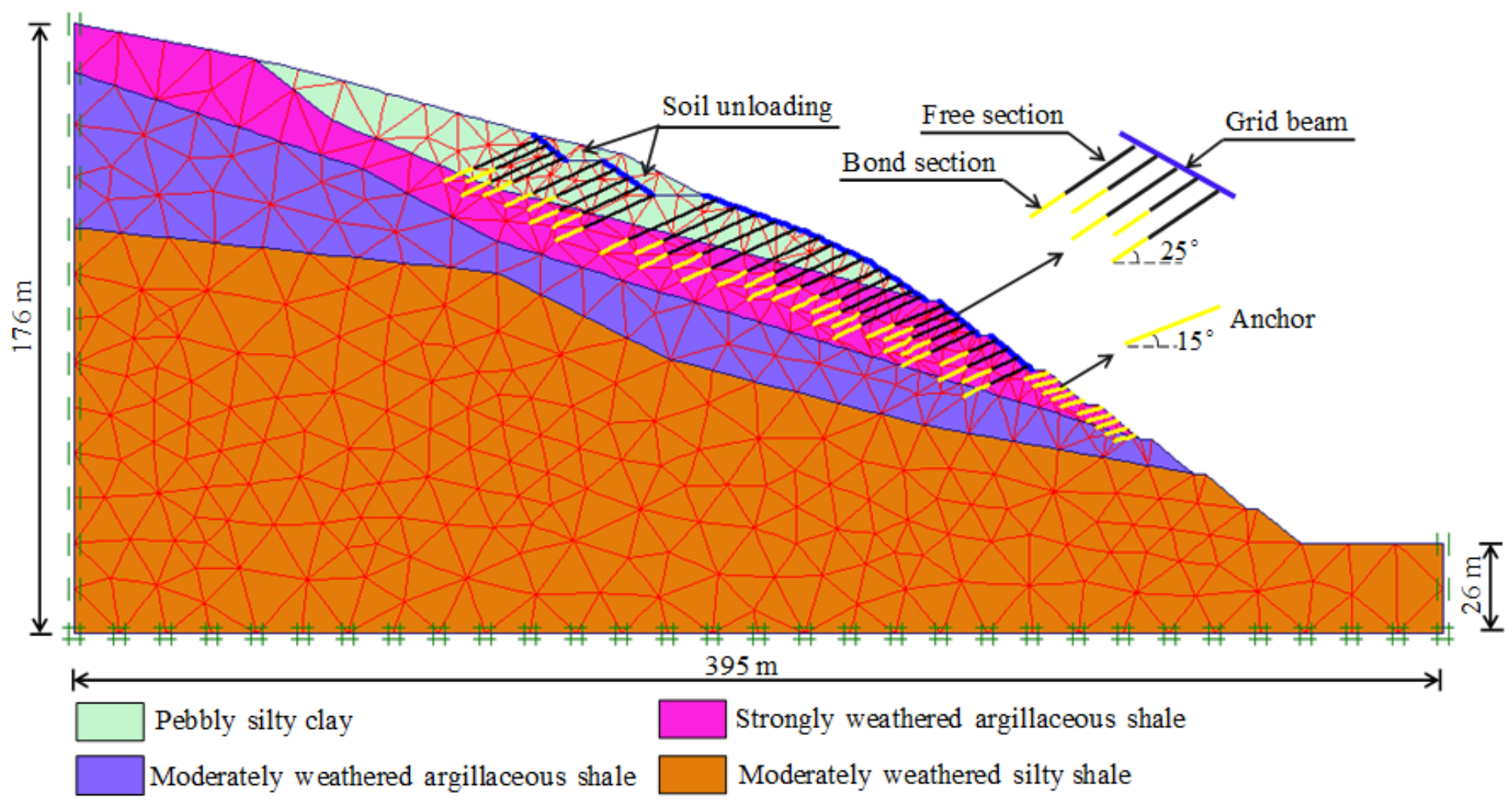




\section{Figure 11}

Numerical model of the slope in PLAXIS

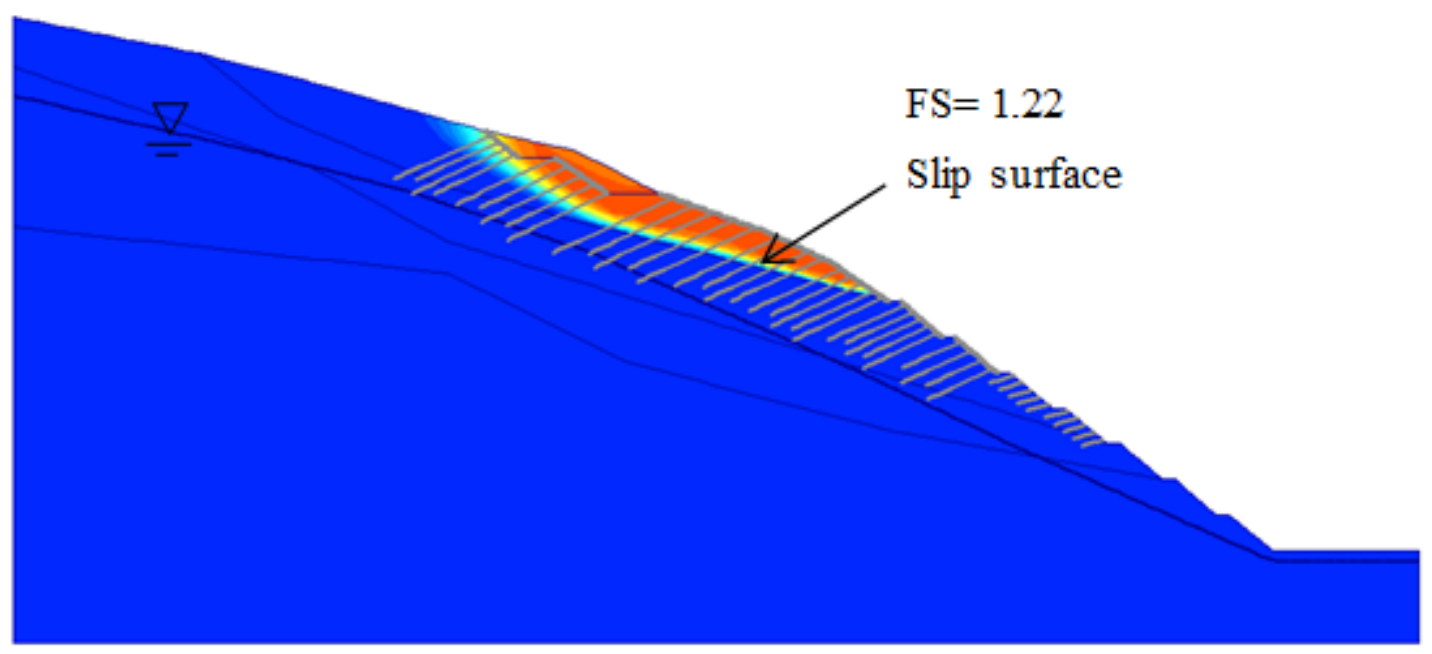

(a)

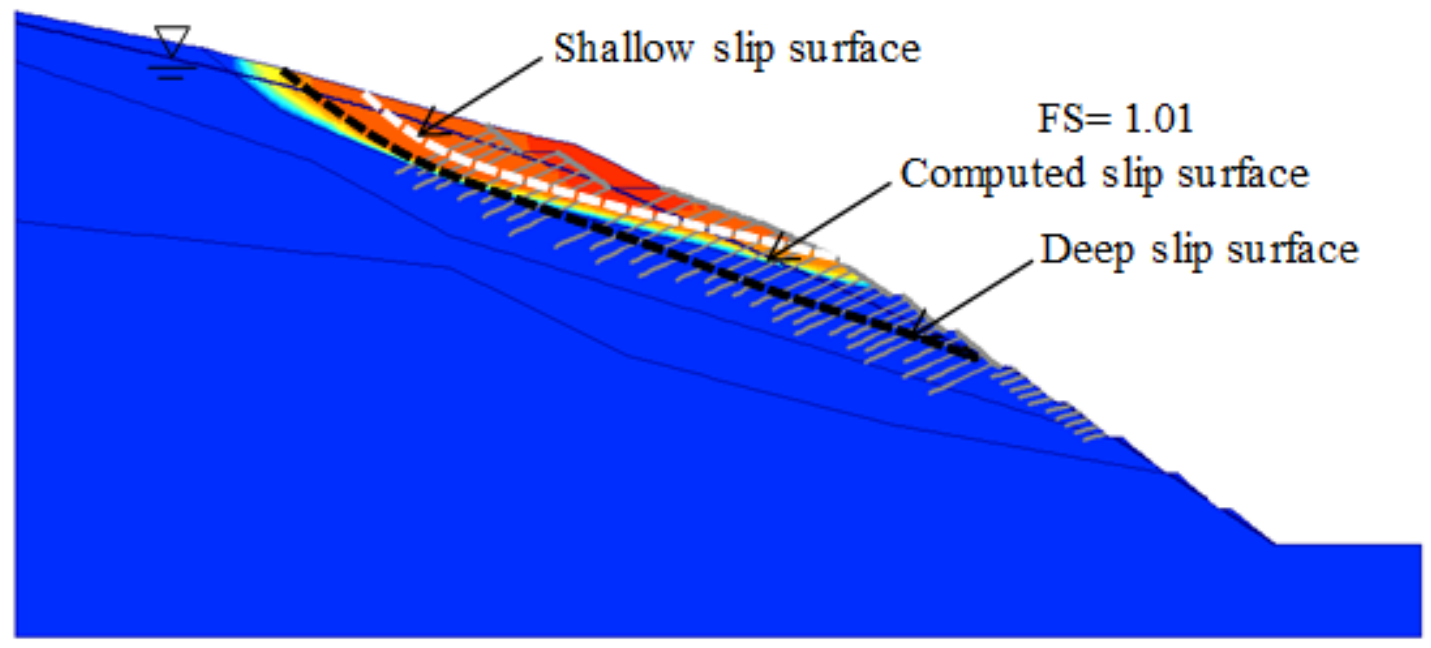

(b)

\section{Figure 12}

Total displacement increment contour of the unreinforced cut-slope: $\mathbf{a}$ under natural conditions; $\mathbf{b}$ under extreme rainfall conditions 


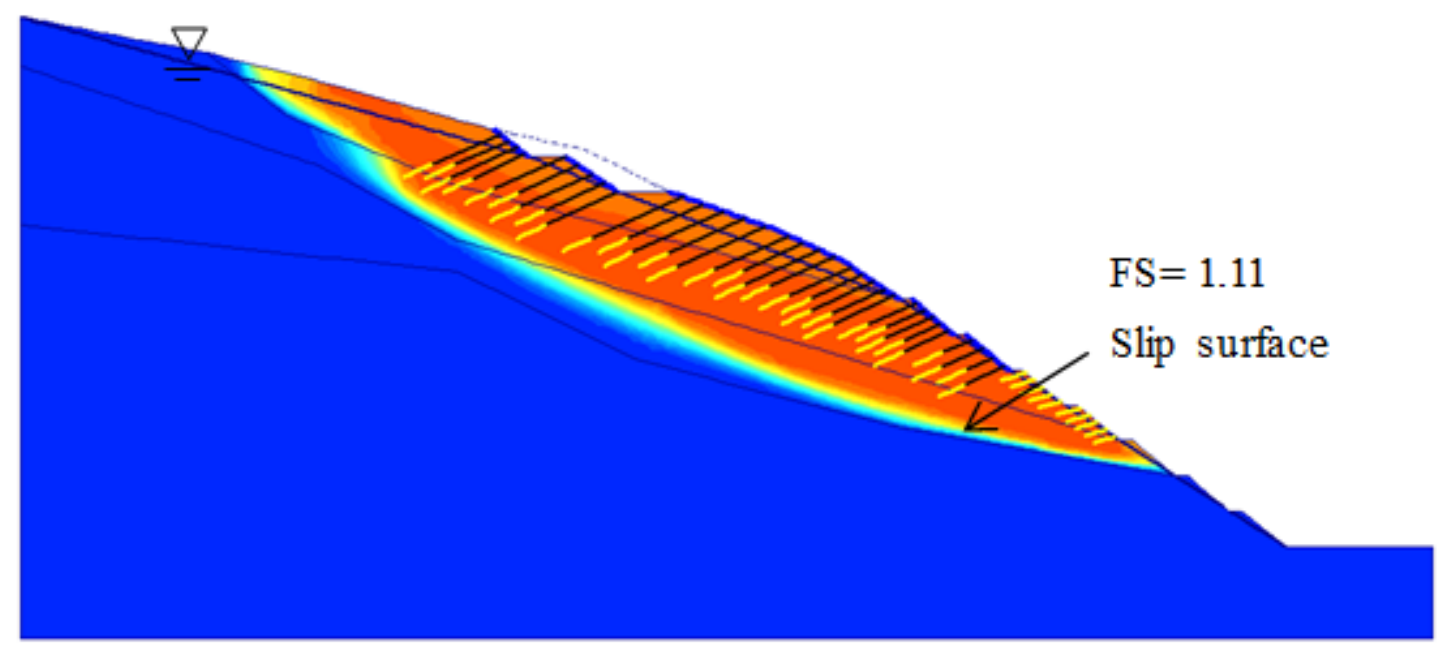

Figure 13

Total displacement increment contour of the reinforced slope under extreme rainfall conditions using soil parameters listed in Table 1

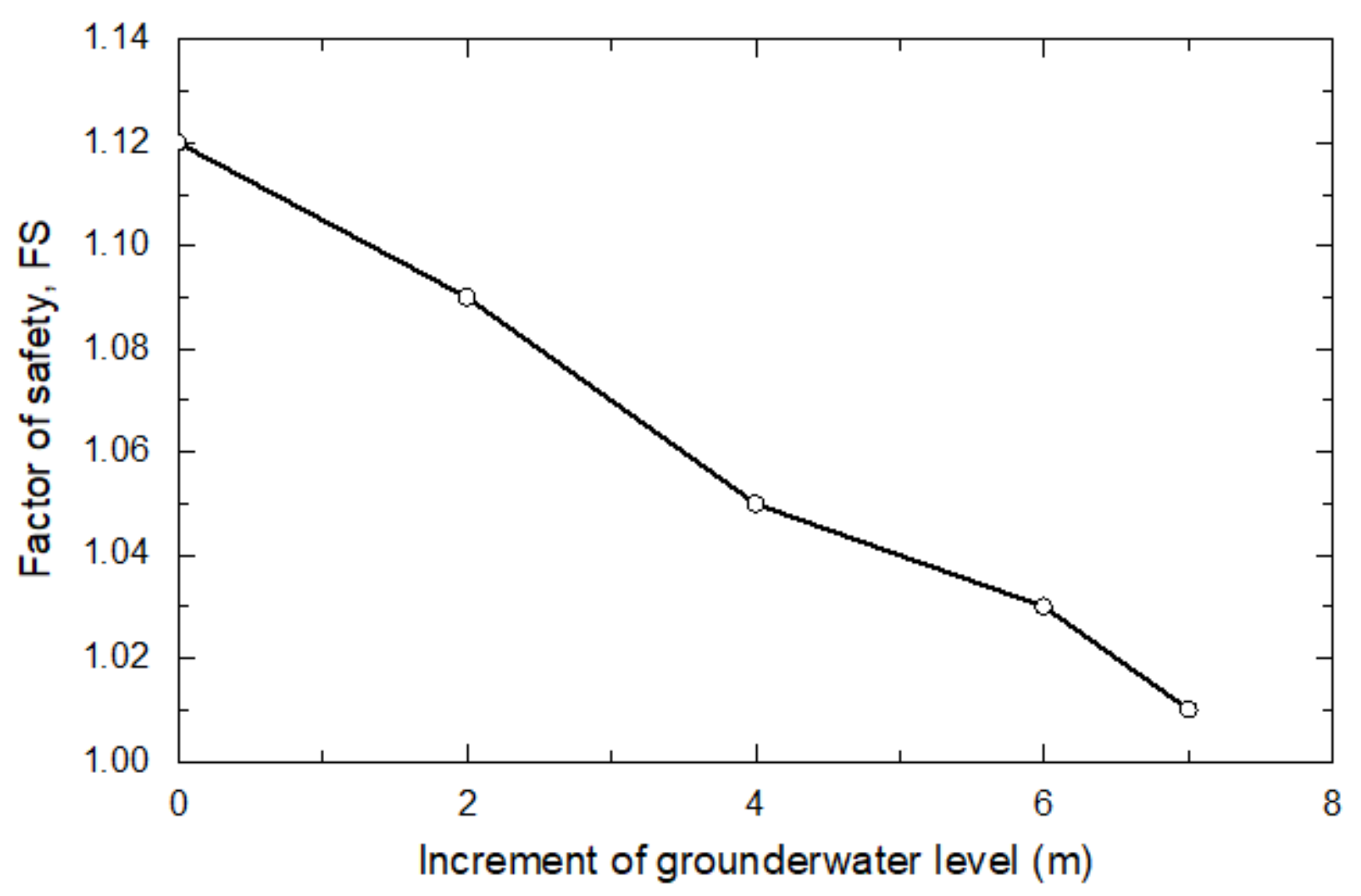

Figure 14

Variation of safety factor with the different increments of groundwater level 


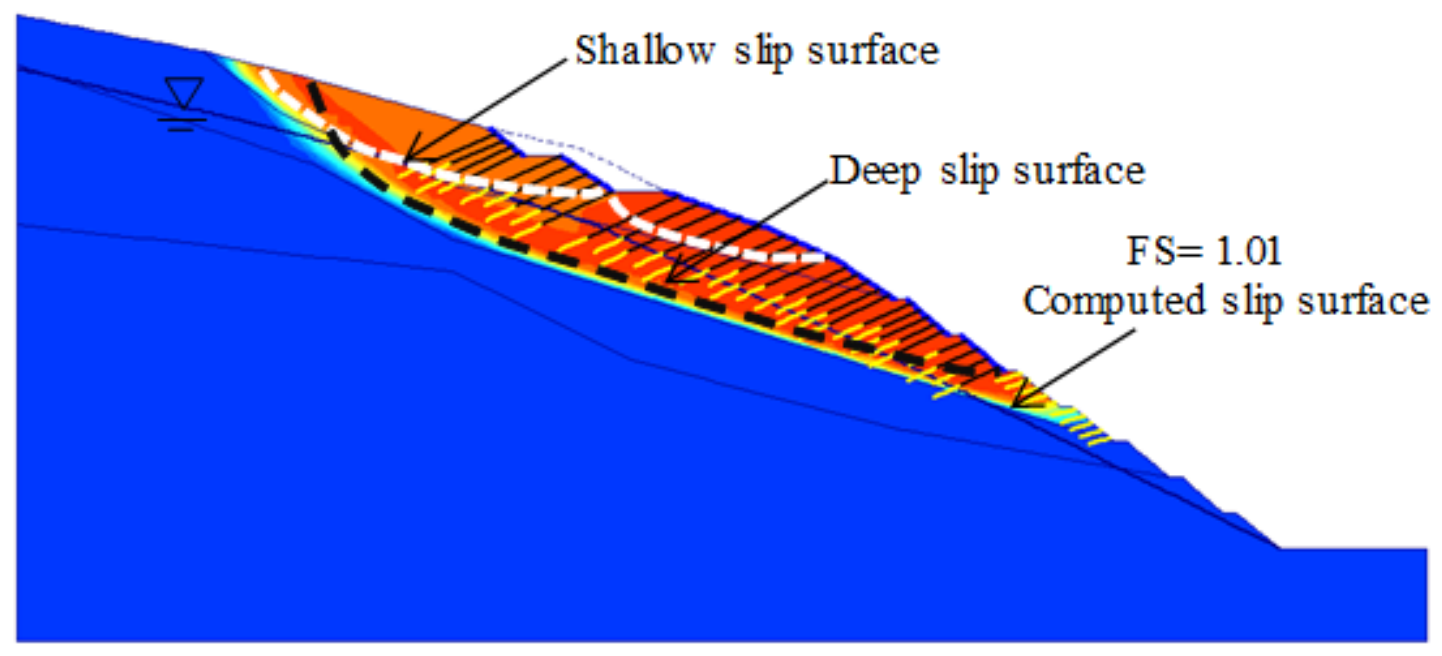

\section{Figure 15}

Total displacement increment contour of the reinforced slope at critical state considering the softening of soils in the top two layers

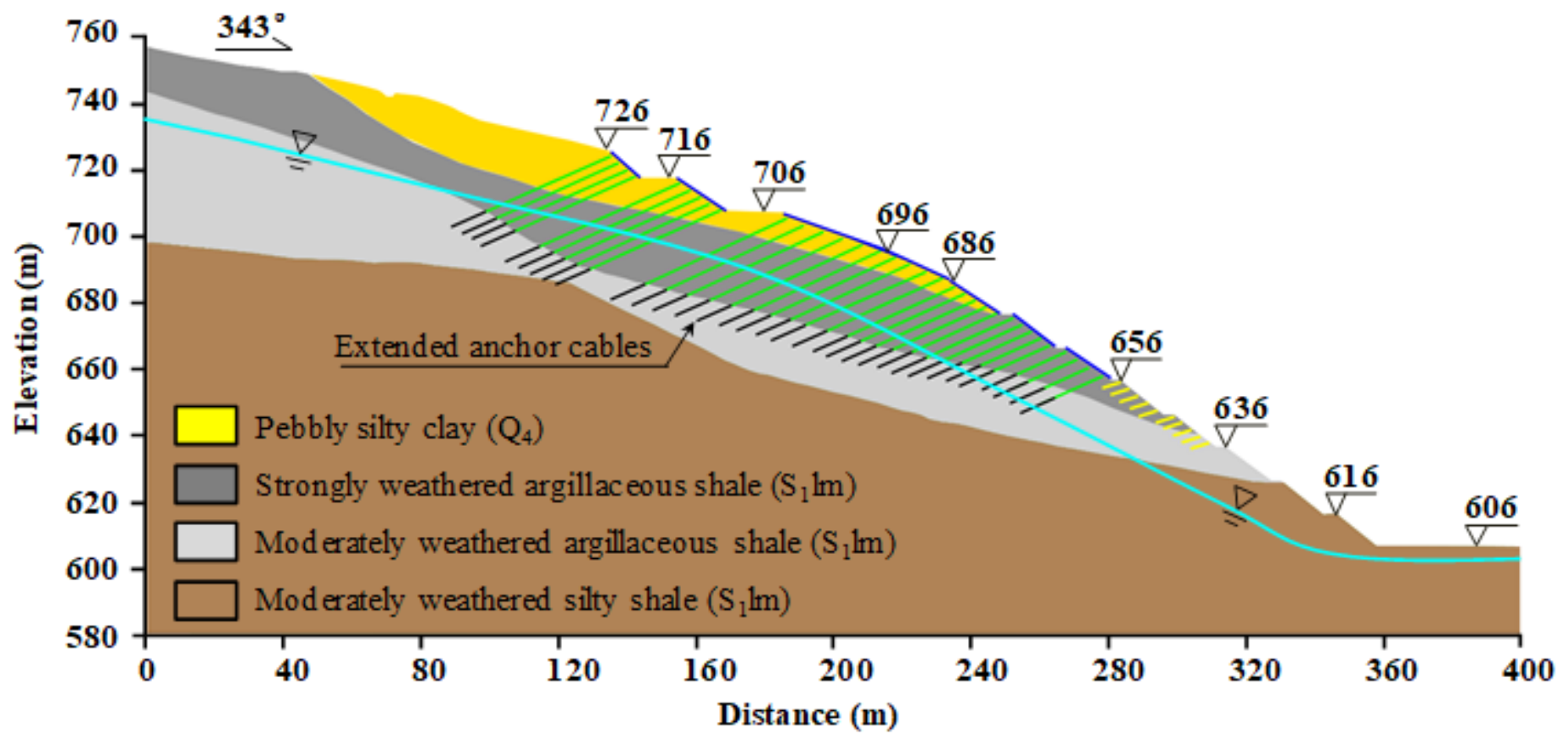

Figure 16

Geological profile of the slope reinforced with extended anchor cables 


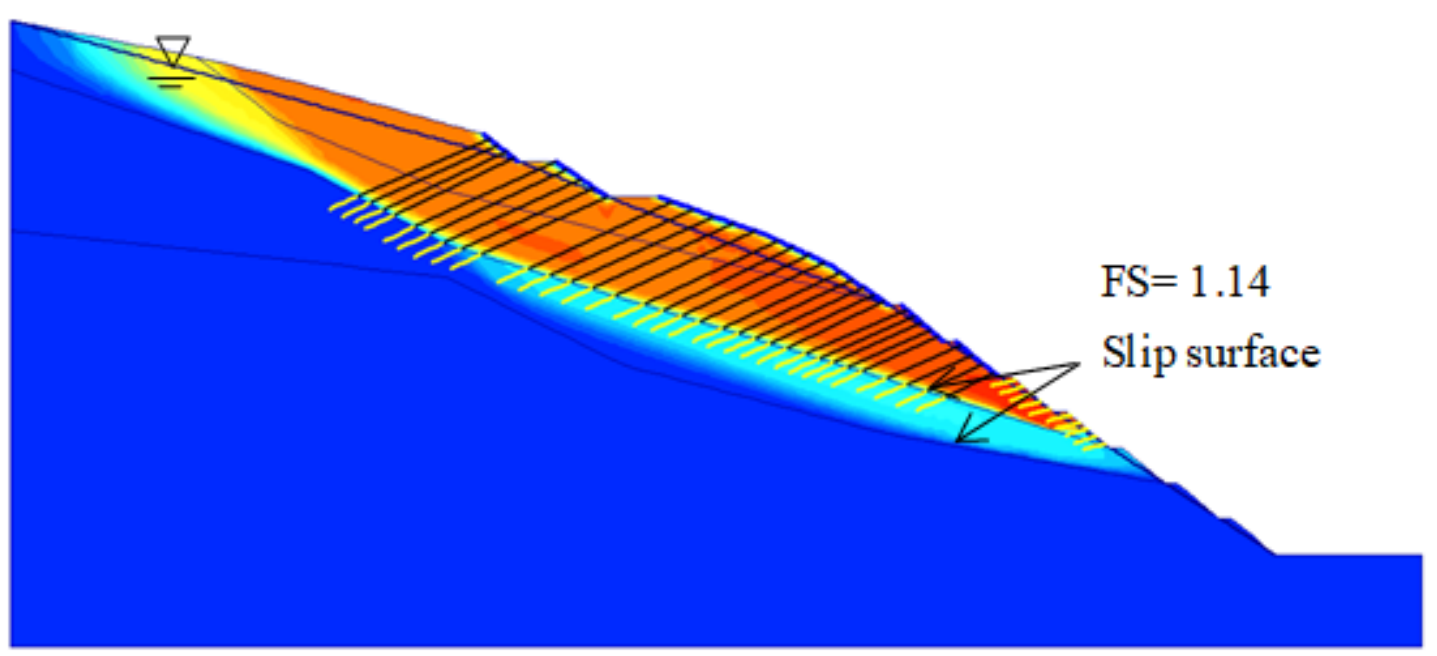

\section{Figure 17}

Total displacement increment contour of the slope reinforced with extended anchor cables under extreme rainfall conditions 